\title{
Evaluation of 18 satellite- and model-based soil moisture products using in situ measurements from 826 sensors
}

\author{
Hylke E. Beck ${ }^{1}$, Ming Pan ${ }^{1}$, Diego G. Miralles ${ }^{2}$, Rolf H. Reichle ${ }^{3}$, Wouter A. Dorigo ${ }^{4}$, Sebastian Hahn ${ }^{4}$, \\ Justin Sheffield $^{5}$, Lanka Karthikeyan ${ }^{6}$, Gianpaolo Balsamo ${ }^{7}$, Robert M. Parinussa ${ }^{8}$, Albert I. J. M. van Dijk ${ }^{9}$, \\ Jinyang Du ${ }^{10}$, John S. Kimball ${ }^{10}$, Noemi Vergopolan ${ }^{1}$, and Eric F. Wood ${ }^{1}$ \\ ${ }^{1}$ Department of Civil and Environmental Engineering, Princeton University, Princeton, NJ, USA \\ ${ }^{2}$ Hydro-Climate Extremes Lab (H-CEL), Ghent University, Ghent, Belgium \\ ${ }^{3}$ Global Modeling and Assimilation Office, NASA Goddard Space Flight Center, Greenbelt, MD, USA \\ ${ }^{4}$ Department of Geodesy and Geoinformation (GEO), Vienna University of Technology, Vienna, Austria \\ ${ }^{5}$ School of Geography and Environmental Science, University of Southampton, Southampton, United Kingdom \\ ${ }^{6}$ Centre of Studies in Resources Engineering, Indian Institute of Technology Bombay, Powai, Mumbai 400 076, India \\ ${ }^{7}$ European Centre for Medium-Range Weather Forecasts (ECMWF), Reading, UK \\ ${ }^{8}$ School of Geographic Sciences, Nanjing University of Information Science \& Technology, \\ Nanjing, Jiangsu, People's Republic of China \\ ${ }^{9}$ Fenner School of Environment and Society, Australian National University, Canberra, Australian Capital Territory, Australia \\ ${ }^{10}$ Numerical Terradynamic Simulation Group, University of Montana, Missoula, MT 59801, USA
}

Correspondence: Hylke E. Beck (hylke.beck@gmail.com)

Received: 24 April 2020 - Discussion started: 19 May 2020

Revised: 9 October 2020 - Accepted: 23 October 2020 - Published: 4 January 2021

\begin{abstract}
Information about the spatiotemporal variability of soil moisture is critical for many purposes, including monitoring of hydrologic extremes, irrigation scheduling, and prediction of agricultural yields. We evaluated the temporal dynamics of 18 state-of-the-art (quasi-)global near-surface soil moisture products, including six based on satellite retrievals, six based on models without satellite data assimilation (referred to hereafter as "open-loop" models), and six based on models that assimilate satellite soil moisture or brightness temperature data. Seven of the products are introduced for the first time in this study: one multi-sensor merged satellite product called MeMo (Merged soil Moisture) and six estimates from the HBV (Hydrologiska Byråns Vattenbalansavdelning) model with three precipitation inputs (ERA5, IMERG, and MSWEP) with and without assimilation of SMAPL3E satellite retrievals, respectively. As reference, we used in situ soil moisture measurements between 2015 and 2019 at $5 \mathrm{~cm}$ depth from 826 sensors, located primarily in the USA and Europe. The 3-hourly Pearson correlation $(R)$ was chosen as the primary performance metric. We found that application of the Soil Wetness Index
\end{abstract}

(SWI) smoothing filter resulted in improved performance for all satellite products. The best-to-worst performance ranking of the four single-sensor satellite products was SMAPL3E $\mathrm{E}_{\mathrm{SWI}}, \mathrm{SMOS}_{\mathrm{SWI}}, \mathrm{AMSR} 2_{\mathrm{SWI}}$, and ASCAT $\mathrm{SWI}_{\text {, }}$ with the L-band-based SMAPL3E $\mathrm{E}_{\mathrm{SWI}}$ (median $R$ of 0.72 ) outperforming the others at $50 \%$ of the sites. Among the two multi-sensor satellite products (MeMo and ESA-CCISWI), MeMo performed better on average (median $R$ of 0.72 versus 0.67 ), probably due to the inclusion of SMAPL3E The best-to-worst performance ranking of the six openloop models was HBV-MSWEP, HBV-ERA5, ERA5-Land, HBV-IMERG, VIC-PGF, and GLDAS-Noah. This ranking largely reflects the quality of the precipitation forcing. HBVMSWEP (median $R$ of 0.78 ) performed best not just among the open-loop models but among all products. The calibration of HBV improved the median $R$ by +0.12 on average compared to random parameters, highlighting the importance of model calibration. The best-to-worst performance ranking of the six models with satellite data assimilation was HBV-MSWEP+SMAPL3E, HBV-ERA5+SMAPL3E, GLEAM, SMAPL4, HBV-IMERG+SMAPL3E, and ERA5. 
The assimilation of SMAPL3E retrievals into HBV-IMERG improved the median $R$ by +0.06 , suggesting that data assimilation yields significant benefits at the global scale.

\section{Introduction}

Accurate and timely information about soil moisture is valuable for many purposes, including drought monitoring, water resources management, irrigation scheduling, prediction of vegetation dynamics and agricultural yields, forecasting floods and heat waves, and understanding climate change impacts (Wagner et al., 2007; Vereecken et al., 2008; Ochsner et al., 2013; Dorigo and de Jeu, 2016; Brocca et al., 2017; Miralles et al., 2019; Tian et al., 2019; Karthikeyan et al., 2020; Chawla et al., 2020). Over recent decades, numerous soil moisture products suitable for these purposes have been developed, each with strengths and weaknesses (see Table 1 for a non-exhaustive overview). The products differ in terms of design objective, spatiotemporal resolution and coverage, data sources, algorithm, and latency. They can be broadly classified into three major categories: (i) products directly derived from active- or passive-microwave satellite observations (Zhang and Zhou, 2016; Karthikeyan et al., 2017b), (ii) hydrological or land surface models without satellite data assimilation (referred to hereafter as open-loop models; Cammalleri et al., 2015; Bierkens, 2015; Kauffeldt et al., 2016; Chen and Yuan, 2020), and (iii) hydrological or land surface models that assimilate soil moisture retrievals or brightness temperature observations from microwave satellites (Moradkhani, 2008; Pan et al., 2009; Pan and Wood, 2010; Liu et al., 2012; Lahoz and De Lannoy, 2014; Reichle et al., 2017).

Numerous studies have evaluated these soil moisture products using in situ soil moisture measurements (e.g., Jackson et al., 2010; Bindlish et al., 2018), other independent soil moisture products (e.g., Chen et al., 2018; Dong et al., 2019), remotely sensed vegetation greenness data (e.g., Tian et al., 2019), or precipitation data (e.g., Crow et al., 2010; Karthikeyan and Kumar, 2016). Pronounced differences in spatiotemporal dynamics and accuracy were found among the products, even among those derived from the same data source. However, most studies evaluated only one specific product or a small subset $(\leq 3)$ of the available products (e.g., Martens et al., 2017; Liu et al., 2019; Zhang et al., 2019; Tavakol et al., 2019). Additionally, many had a regional (subcontinental) focus (e.g., Albergel et al., 2009; Gruhier et al., 2010; Griesfeller et al., 2016), potentially leading to conclusions with limited generalizability. Furthermore, several new or recently reprocessed products have not been thoroughly evaluated yet, such as ERA5 (Hersbach et al., 2020), ERA5Land (C3S, 2019), and ESA-CCI V04.4 (Dorigo et al., 2017). There is also still uncertainty around, for example, the effectiveness of multi-sensor merging techniques (Petropoulos et al., 2015), the impact of model complexity on the accuracy of soil moisture simulations (Fatichi et al., 2016), the degree to which model deficiencies and precipitation data quality affect the added value of data assimilation (Xia et al., 2019), and the impact of smoothing filters such as the Soil Wetness Index (SWI; Wagner et al., 1999; Albergel et al., 2008) on the performance ranking of products.

Our main objective was to undertake a comprehensive evaluation of 18 state-of-the-art (quasi-)global near-surface soil moisture products in terms of their temporal dynamics (Sect. 2.1). Our secondary objective was to introduce seven new soil moisture products (one multi-sensor merged satellite product called MeMo introduced in Sect. 2.2 and six HBV model-based products introduced in Sect. 2.3 and 2.4). As reference for the evaluation, we used in situ soil moisture measurements between 2015 and 2019 from 826 sensors located primarily in the USA and Europe (Sect. 2.5). We aim to shed light on the advantages and disadvantages of different soil moisture products and on the merit of various technological and methodological innovations by addressing nine key questions frequently faced by researchers and end users alike:

1. How do the ascending and descending retrievals perform (Sect. 3.1)?

2. What is the impact of the SWI smoothing filter (Sect. 3.2)?

3. What is the relative performance of the single-sensor satellite products (Sect. 3.3)?

4. How do the multi-sensor merged satellite products perform (Sect. 3.4)?

5. What is the relative performance of the open-loop models (Sect. 3.5)?

6. How do the models with satellite data assimilation perform (Sect. 3.6)?

7. What is the impact of model calibration (Sect. 3.7)?

8. How do the major product categories compare (Sect. 3.8)?

9. To what extent are our results generalizable to other regions (Sect. 3.9)?

\section{Data and methods}

\subsection{Soil moisture products}

We evaluated in total 18 near-surface soil moisture products, including six based on satellite observations, six based on open-loop models, and six based on models that assimilate satellite data (Table 1). We evaluated six products 


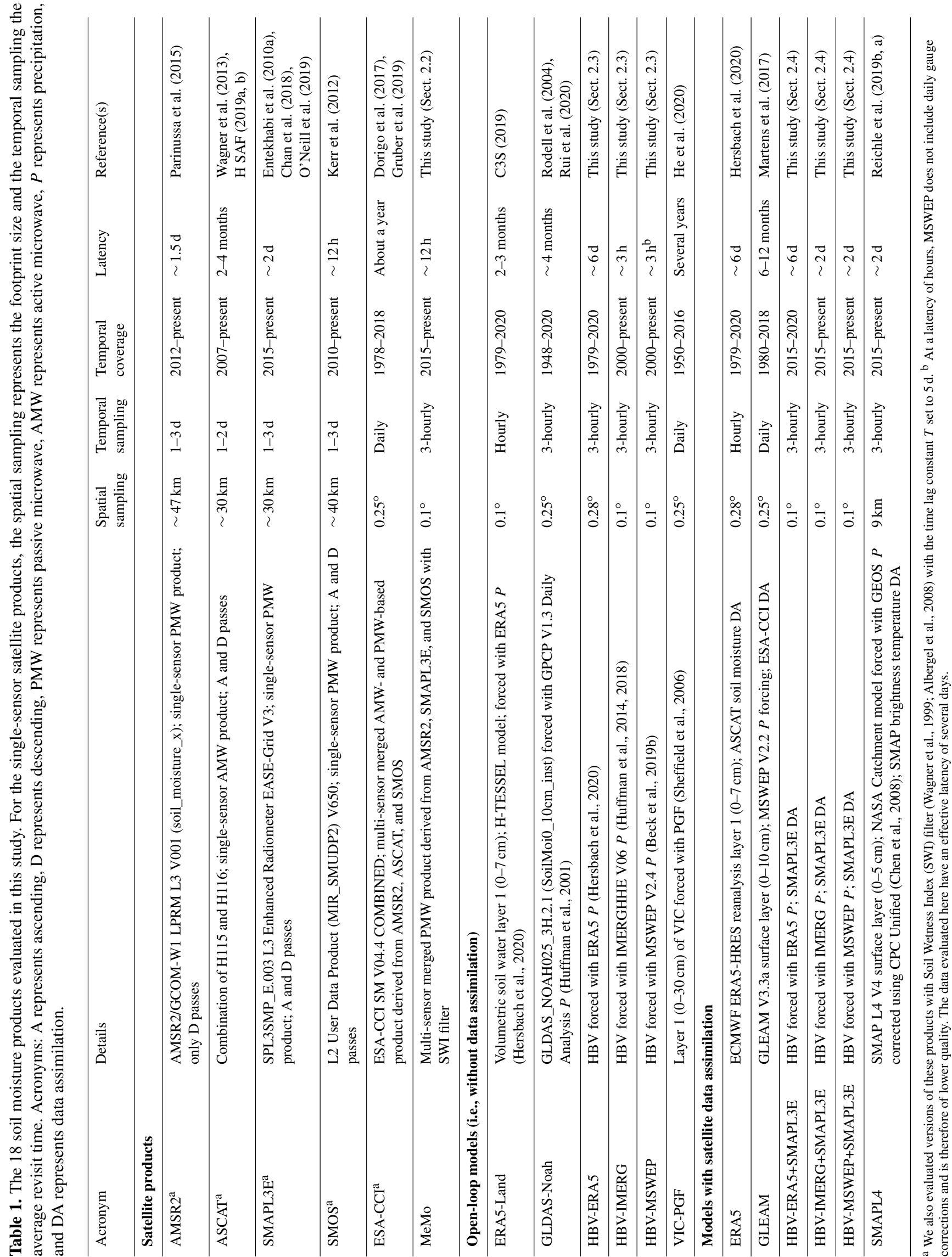


per category, which was sufficient to compare the performance among and within product categories and address the questions posed in the introduction. We only considered widely used products with (quasi-)global coverage, and we attempted to keep the selection of products in each category as diverse as possible. For example, we considered products based on several major satellite missions used for global soil moisture mapping (AMSR2, ASCAT, SMAP, and SMOS), models of various type and complexity (with and without calibration), different sources of precipitation data (satellites, reanalyses, gauges, and combinations thereof), and various data merging and assimilation techniques (with different inputs).

The units differed among the products; some are provided in volumetric water content (typically expressed in $\mathrm{m}^{3} \mathrm{~m}^{-3}$, e.g., ERA5) and others in degree of saturation (typically expressed in percent (\%), e.g., ASCAT). We did not harmonize the units among the products, because the Pearson correlation coefficient - the performance metric used in the current study (Sect. 2.6) - is insensitive to the units. Since the evaluation was performed at a 3-hourly resolution, we downscaled the two products with a daily temporal resolution (VIC-PGF and GLEAM) to a 3-hourly resolution using nearest-neighbor resampling (resulting in replication of the daily value for all 3-hourly periods on each day). In contrast to the model products, the satellite products (with the exception of ASCAT) often do not provide retrievals when the soil is frozen or covered by snow (Fig. S1 in the Supplement). To keep the evaluation consistent, we used ERA5 (Hersbach et al., 2020) to discard the estimates of all 18 products when the near-surface soil temperature of layer $1(0-7 \mathrm{~cm})$ was $<4{ }^{\circ} \mathrm{C}$ and/or the snow depth was $>1 \mathrm{~mm}$.

To deepen the vertical support of the superficial satellite observations and suppress noise, we also evaluated 3-hourly versions of the satellite products processed using the SWI exponential smoothing filter (Wagner et al., 1999; Albergel et al., 2008). MeMo was not processed as it was derived from SWI-filtered products. The SWI filter is defined according to

$\operatorname{SWI}(t)=\frac{\sum_{i} \operatorname{SM}_{\mathrm{sat}}\left(t_{i}\right) e^{-\frac{t-t_{i}}{T}}}{\sum_{i} e^{-\frac{t-t_{i}}{T}}}$,

where $\mathrm{SM}_{\mathrm{sat}}$ (units depend on the product) is the soil moisture retrieval at time $t_{i}, T(\mathrm{~d})$ represents the time lag constant, and $t$ represents the 3-hourly time step. $T$ was set to $5 \mathrm{~d}$ for all products, as the performance did not change markedly using different values, as also reported in previous studies (Albergel et al., 2008; Beck et al., 2009; Ford et al., 2014; Pablos et al., 2018). Following Pellarin et al. (2006), SWI at time $t$ was only calculated if $\geq 1$ retrievals were available in the interval $(t-T, t]$ and $\geq 3$ retrievals were available in the interval $[t-3 T, t-T]$. Figure 1 illustrates the filter for the SMAPL3 product.

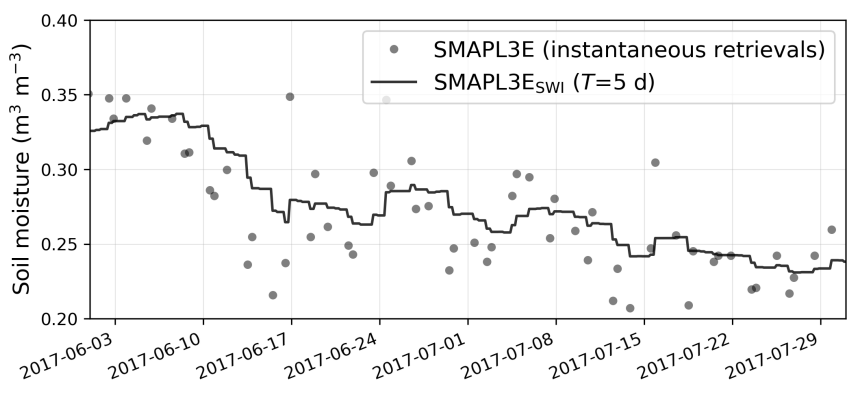

Figure 1. To illustrate the SWI filter, SMAPL3E instantaneous volumetric soil moisture retrievals (from both ascending and descending overpasses) and 3-hourly SMAPL3E $\mathrm{SWI}_{\mathrm{SW}}$ time series obtained by application of the SWI filter (with the time lag constant $T$ set to $5 \mathrm{~d}$ ) for a 2 -month period at $34.82^{\circ} \mathrm{N}, 89.44^{\circ} \mathrm{W}$.

The vertical support is physically consistent with in situ soil moisture measurements at $5 \mathrm{~cm}$ depth for most models. The average depth of the soil layer (i.e., half the depth of the lower boundary) is $2.5 \mathrm{~cm}$ for SMAPL4, $3.5 \mathrm{~cm}$ for ERA5 and ERA5-Land, $5 \mathrm{~cm}$ for GLEAM, $8.5 \mathrm{~cm}$ for HBVERA5, $6.6 \mathrm{~cm}$ for HBV-IMERG, $7.3 \mathrm{~cm}$ for HBV-MSWEP, and $15 \mathrm{~cm}$ for VIC-PGF (Tables 1 and S1). The soil layers of HBV may seem too deep, especially since they represent conceptual "buckets" that can be fully filled with water, in contrast to the soil layers of the other models which additionally consist of mineral and organic matter. However, the soil layer depths of HBV were calibrated (see Sect. 2.3) and are thus empirically consistent with in situ measurements at $5 \mathrm{~cm}$ depth.

\subsection{Merged soil Moisture (MeMo) product}

Merged soil Moisture (MeMo) is a new 3-hourly soil moisture product derived by merging the soil moisture anomalies of three single-sensor passive-microwave satellite products with SWI filter (AMSR2 ${ }_{S W I}$, SMAPL3E SWI $_{\text {, and SMOS }}$ SWI; Table 1). MeMo was produced for 2015-2019 (the period with data for all three products) as follows:

1. Three-hourly soil moisture time series of AMSR2 ${ }_{\text {SWI }}$, SMAPL3E $_{S W I}$, SMOS $_{S W I}$, the active-microwave satellite product $\mathrm{ASCAT}_{\mathrm{SWI}}$, and the open-loop model HBVMSWEP were normalized by subtracting the long-term means and dividing by the long-term standard deviations of the respective products (calculated for the period of overlap).

2. Three-hourly anomalies were calculated for the five products by subtracting their respective seasonal climatologies. The seasonal climatology was calculated by taking the multi-year mean for each day of the year, after which we applied a $30 \mathrm{~d}$ central moving mean to eliminate noise. The moving mean was only calculated if $>21 \mathrm{~d}$ with values were present in the $30 \mathrm{~d}$ window. Due to the large number of missing values in winter 
(Fig. S1), we were not able to compute the seasonality and, in turn, the anomalies in winter for some satellite products.

3. Time-invariant merging weights for AMSR2 ${ }_{\text {SWI }}$, SMAPL3E $\mathrm{E}_{\mathrm{SWI}}$, and $\mathrm{SMOS}_{\mathrm{SWI}}$ were calculated using extended triple collocation (McColl et al., 2014), a technique to estimate Pearson correlation coefficients $(R)$ for independent products with respect to an unknown truth. The $R$ values for the respective products were determined using the triplet consisting of the product in question in combination with ASCAT and HBV-MSWEP, which are independent from each other and from the passive products. The $R$ values were only calculated if $>200$ coincident anomalies were available. The weights were calculated by squaring the $R$ values.

4. For each 3-hourly time step, we calculated the weighted mean of the available anomalies of AMSR2 ${ }_{S W I}$, SMAPL3E $\mathrm{E}_{\mathrm{SWI}}$, and SMOS $\mathrm{SWI}_{\mathrm{SW}}$. If only one anomaly was available, this value was used and no averaging was performed. The climatology of SMAPL3E - the best-performing product in our evaluation - was subsequently added to the result, to yield the MeMo soil moisture estimates.

\subsection{HBV hydrological model}

Six new 3-hourly soil moisture products were produced using the Hydrologiska Byråns Vattenbalansavdelning (HBV) conceptual hydrological model (Bergström, 1976, 1992) forced with three different precipitation datasets and with and without assimilation of SMAPL3E soil moisture estimates, respectively (Table 1). HBV was selected because of its low complexity, high agility, computational efficiency, and successful application used in numerous studies spanning a wide range of climate and physiographic conditions (e.g., SteeleDunne et al., 2008; Driessen et al., 2010; Beck et al., 2013; Vetter et al., 2015; Jódar et al., 2018). The model has 1 soil moisture store, 2 groundwater stores, and 12 free parameters. Among the 12 free parameters, 7 are relevant for simulating soil moisture as they pertain to the snow or soil routines, while 5 are irrelevant for this study as they pertain to runoff generation or deep percolation. The soil moisture store has two inputs (precipitation and snowmelt) and two outputs (evaporation and recharge). The model was run twice for 2010-2019: the first time to initialize the soil moisture store and the second time to obtain the final outputs.

HBV requires time series of precipitation, potential evaporation, and air temperature as input. For precipitation, we used three different datasets: (i) the reanalysis ERA5 (hourly $0.28^{\circ}$ resolution; Hersbach et al., 2020); (ii) the satellitebased IMERG dataset (Late Run V06; 30 min $0.1^{\circ}$ resolution; Huffman et al., 2014, 2018); and (iii) the gauge-, satellite-, and reanalysis-based MSWEP dataset (V2.4; 3- hourly $0.1^{\circ}$ resolution; Beck et al., 2017b, 2019b). For the ERA5 and IMERG datasets, we calculated 3-hourly precipitation accumulations. Daily potential evaporation was estimated using the Hargreaves (1994) equation from daily minimum and maximum air temperature. The daily potential evaporation data were downscaled to 3-hourly using nearestneighbor resampling. Air temperature estimates were taken from ERA5. To improve the representation of mountainous regions and ameliorate potential biases, the ERA5 air temperature data were matched on a monthly climatological basis using an additive (as opposed to multiplicative) approach to the comprehensive station-based WorldClim climatology (V2; $1 \mathrm{~km}$ resolution; Fick and Hijmans, 2017).

We calibrated the 7 relevant parameters of HBV using in situ soil moisture measurements from 177 independent sensors from the International Soil Moisture Network (ISMN) archive (Sect. 2.5; Fig. S2). These sensors did not have enough measurements during the evaluation period (31 March 2015 to 16 September 2019) and thus were available for an independent calibration exercise. The parameter space was explored by generating $N=500$ candidate parameter sets using Latin hypercube sampling (McKay et al., 1979), which splits the parameter space up into $N$ equal intervals and generates parameter sets by sampling each interval once in a random manner. The model was subsequently run for all candidate parameter sets, after which we selected the parameter set with the best overall performance across the 177 sites (Table S1). As objective function, we used the median Pearson correlation coefficient $(R)$ calculated between 3-hourly in situ and simulated soil moisture time series. To avoid giving one of the precipitation datasets an unfair advantage, we recalibrated the model for each of the three precipitation datasets (ERA5, IMERG, and MSWEP).

\subsection{Soil moisture data assimilation}

Instantaneous soil moisture retrievals (without SWI filter) from SMAPL3E (Table 1) were assimilated into the HBV model forced with the three above-mentioned precipitation datasets (ERA5, IMERG, and MSWEP). Previous regional studies that successfully used HBV to assess the value of data assimilation include Parajka et al. (2006), Montero et al. (2016), and Lü et al. (2016). We used the simple Newtonian nudging technique of Houser et al. (1998) that drives the soil moisture state of the model towards the satellite observations. Nudging techniques are computationally efficient and easy to implement, and they have therefore been used in several studies (e.g., Brocca et al., 2010b; Dharssi et al., 2011; Capecchi and Brocca, 2014; Laiolo et al., 2016; Cenci et al., 2016; Martens et al., 2016). For each grid cell, the soil moisture state of the model was updated when a satellite observation was available according to

$\mathrm{SM}_{\text {mod }}^{+}(t)=\mathrm{SM}_{\text {mod }}^{-}(t)+k G\left[\mathrm{SM}_{\mathrm{sat}}^{\mathrm{sc}}(t)-\mathrm{SM}_{\text {mod }}^{-}(t)\right]$, 
where $\mathrm{SM}_{\text {mod }}^{+}$and $\mathrm{SM}_{\text {mod }}^{-}(\mathrm{mm})$ are the updated and a priori soil moisture states of the model, respectively; $\mathrm{SM}_{\mathrm{sat}}^{\mathrm{sc}}(\mathrm{mm})$ represents the rescaled satellite observations; and $t$ is the 3hourly time step. The satellite observations were rescaled to the open-loop model space using cumulative distribution function (CDF) matching (Reichle and Koster, 2004).

The nudging factor $k(-)$ was set to 0.1 as this gave satisfactory results. The gain parameter $G(-)$ determines the magnitude of the updates and ranges from 0 to $1 . G$ is generally calculated based on relative quality of the satellite retrievals and the open-loop model. Most previous studies used a spatially and temporally uniform $G$ (e.g., Brocca et al., 2010b; Dharssi et al., 2011; Capecchi and Brocca, 2014; Laiolo et al., 2016; Cenci et al., 2016). Conversely, Martens et al. (2016) used the triple collocation technique (Scipal et al., 2008) to obtain spatially variable $G$ values. Here we calculated $G$ in a similar fashion according to

$G=\frac{R_{\mathrm{sat}}^{2}}{R_{\mathrm{sat}}^{2}+R_{\mathrm{mod}}^{2}}$

where $R_{\text {sat }}$ and $R_{\text {mod }}(-)$ are Pearson correlation coefficients with respect to an unknown truth for SMAPL3E and HBV, respectively, calculated using extended triple collocation (Sect. 2.2). $R_{\text {sat }}$ was determined using 3-hourly anomalies of the triplet SMAPL3E, ASCAT SWI $_{\text {, and HBV- }}$ MSWEP (Table 1) which are based on passive microwaves, active microwaves, and an open-loop model, respectively. $R_{\text {mod }}$ was determined using 3-hourly anomalies of the triplet HBV (forced with either ERA5, IMERG, or MSWEP), ASCAT $_{S W I}$, and SMAPL3E $E_{S W I}$. The anomalies were calculated by subtracting the seasonal climatologies of the respective products. The seasonal climatologies were determined as described in Sect. 2.2. The $R_{\text {sat }}$ and $R_{\text {mod }}$ values were only calculated if $>200$ coincident anomalies were available. The resulting $G$ values vary in space but are constant in time.

\subsection{In situ soil moisture measurements}

As reference for the evaluation, we used harmonized and quality-controlled in situ volumetric soil moisture measurements $\left(\mathrm{m}^{3} \mathrm{~m}^{-3}\right)$ from the ISMN archive (Dorigo et al., 2011; Dorigo et al., 2013; Appendix Table A1). The measurements were performed using various types of sensors, including time-domain reflectometry sensors, frequency-domain reflectometry sensors, capacitance sensors, and cosmic-ray neutron sensors, among others. Similar to numerous previous evaluations (e.g., Albergel et al., 2009; Champagne et al., 2010; Albergel et al., 2012; Wu et al., 2016), we selected measurements from sensors at a depth of $5 \mathrm{~cm}( \pm 2 \mathrm{~cm})$. Since the evaluation was performed at a 3-hourly resolution, the measurements in the ISMN archive, which have a hourly resolution, were resampled to a 3-hourly resolution. We only used sensors with a 3-hourly record length $>1$ year (not necessarily consecutive) during the evaluation period from 31 March 2015 to 16 September 2019. We did not average the measurements of sites with multiple sensors to avoid potentially introducing discontinuities in the time series. In total 826 sensors, located in the USA (692), Europe (117), and Australia (17), were available for evaluation (Fig. 2). The median record length was 3.0 years.

\subsection{Evaluation approach}

We evaluated the 18 near-surface soil moisture products (Table 1) for the 4.5-year-long period from 31 March 2015 (the date on which SMAP data became available), to 16 September 2019 (the date on which we started processing the products). As performance metric, we used the Pearson correlation coefficient $(R)$ calculated between 3-hourly soil moisture time series from the in situ sensors and the products, similar to numerous previous studies (e.g., Karthikeyan et al., 2017a; Al-Yaari et al., 2017; Kim et al., 2018). $R$ measures how well the in situ and product time series correspond in terms of temporal variability, and thus it evaluates the most important aspect of soil moisture time series for the majority of applications (Entekhabi et al., 2010b; Gruber et al., 2020). It is insensitive to systematic differences in mean and variance, which can be substantial due to (i) the use of different soil property maps as input to the retrieval algorithms and hydrological models (Teuling et al., 2009; Koster et al., 2009) and (ii) the inherent scale discrepancy between in situ point measurements and satellite footprints or model grid cells (Miralles et al., 2010; Crow et al., 2012; Gruber et al., 2020).

Additionally, to quantify the performance of the products at different timescales, we calculated Pearson correlation coefficients for the low-frequency fluctuations (i.e., the slow variability at monthly and longer timescales; $R_{\mathrm{lo}}$ ) and the high-frequency fluctuations (i.e., the fast variability at 3hourly to monthly timescales; $R_{\mathrm{hi}}$ ). The low-frequency fluctuations were isolated using a $30 \mathrm{~d}$ central moving mean, similar to previous studies (e.g., Albergel et al., 2009; Al-Yaari et al., 2014; Su et al., 2016). The moving mean was calculated only if $>21 \mathrm{~d}$ with estimates were present in the $30 \mathrm{~d}$ window. The high-frequency fluctuations were isolated by subtracting the low-frequency fluctuations from the original 3-hourly time series.

To ensure a fair evaluation, we discarded the estimates of all products when the near-surface soil temperature was $<4{ }^{\circ} \mathrm{C}$ and/or the snow depth was $>1 \mathrm{~mm}$ (both determined using ERA5; Hersbach et al., 2020). For the satellite products without SWI filter, we matched the instantaneous soil moisture retrievals with coincident 3-hourly in situ measurements to compute the $R$ values. Since the evaluation was performed at a 3-hourly resolution, we downscaled the two products with a daily temporal resolution (VIC-PGF and GLEAM; Table 1) to a 3-hourly resolution using nearest-neighbor resampling. To ensure reliable $R$ values, we only calculated $R, R_{\mathrm{hi}}$, or $R_{\mathrm{lo}}$ values if $>200$ coincident soil moisture estimates from the sensor and the product were available. The 
(a) Alaska

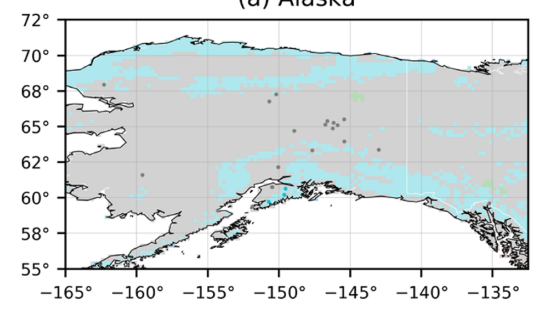

(A) Tropical $(n=9)$

(B) Arid $(n=313)$

(C) Temperate $(n=183)$

(D) Cold $(n=321)$

(E) Polar $(n=3)$

(c) Conterminous US

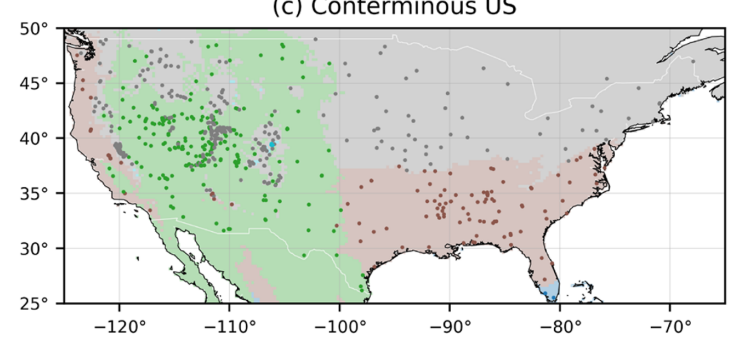

(b) Europe

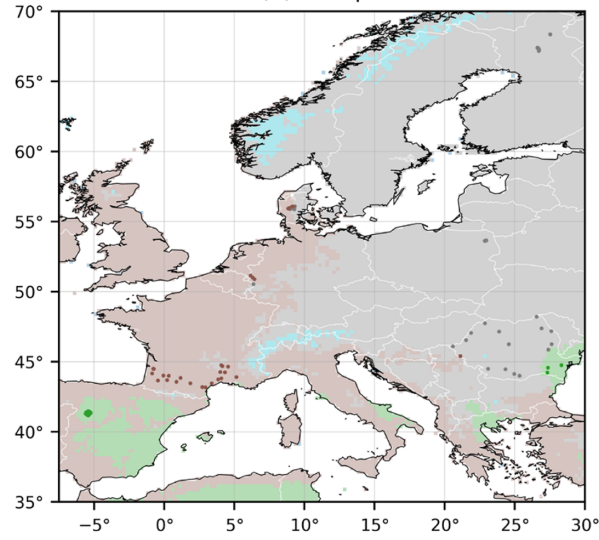

(d) Southeast Australia

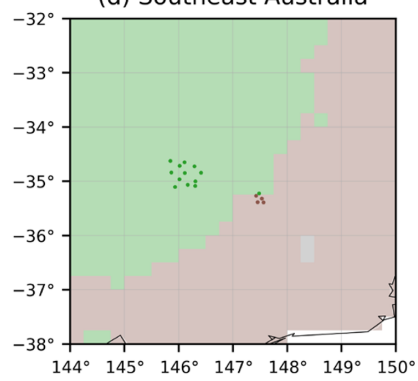

Figure 2. Major Köppen-Geiger climate class (Beck et al., 2018) of the 826 sensors used as reference. $n$ denotes the number of sensors in each class.

final numbers of $R, R_{\mathrm{hi}}$, and $R_{\mathrm{lo}}$ values thus varied depending on the product.

To derive insights into the reasons for the differences in performance, median $R$ values were calculated separately for different Köppen-Geiger climate classes, leaf area index (LAI) values, and topographic slopes. To determine the Köppen-Geiger climate classes, we used the $1 \mathrm{~km}$ KöppenGeiger climate classification map of Beck et al. (2018; Fig. 2), which represents the period 1980-2016. To determine LAI, we used the $1 \mathrm{~km}$ Copernicus LAI dataset derived from SPOT-VGT and PROBA-V data (V2; Baret et al., 2016; mean over 1999-2019). To determine the topographic slope, we used the $90 \mathrm{~m}$ MERIT DEM (Yamazaki et al., 2017). To reduce the scale mismatch between point locations and satellite sensor footprints or model grid cells, we upscaled the Köppen-Geiger, LAI, and topographic slope maps to $0.25^{\circ}$ using majority, average, and average resampling, respectively.

\section{Results and discussion}

\subsection{How do the ascending and descending retrievals perform?}

Microwave soil moisture retrievals from ascending and descending overpasses may exhibit performance differences due to diurnal variations in land surface conditions (Lei et al., 2015) and radio-frequency interference (RFI; Aksoy and Johnson, 2013). Table 2 presents $R$ values for the instantaneous ascending and descending retrievals of the four singlesensor products (AMSR2, ASCAT, SMAPL3E, and SMOS; Table 1). Descending (local night) retrievals were more reliable for the passive-microwave-based AMSR2, in agreement with several previous studies (Lei et al., 2015; Griesfeller et al., 2016; Bindlish et al., 2018), and consistent with the notion that soil-vegetation temperature differences during daytime interfere with passive-microwave soil moisture retrieval (Parinussa et al., 2011). Descending (local morning) retrievals were more reliable for the active-microwavebased ASCAT (Table 2), in agreement with Lei et al. (2015). The ascending and descending retrievals performed similarly for the passive-microwave-based SMAPL3E and SMOS (Table 2). For the remainder of this analysis, we will use only descending retrievals of AMSR2. We did not discard the ascending retrievals of ASCAT as they helped to improve the performance of $\mathrm{ASCAT}_{\mathrm{SWI}}$.

\subsection{What is the impact of the Soil Wetness Index (SWI) smoothing filter?}

The application of the SWI filter resulted in higher median $R, R_{\mathrm{hi}}$, and $R_{\mathrm{lo}}$ values for all satellite products (Figs. 3a and 4; Table 1). The median $R$ improvement was +0.12 for 
Table 2. Median Pearson correlations $(R)$ between in situ measurements and retrievals from ascending and descending overpasses for the single-sensor soil moisture products (Table 1). The approximate local solar time (LST) of the overpasses is reported in parentheses. Probability $(p)$ values were determined using the Kruskal and Wallis (1952) test. A small $p$ value indicates that the difference in median $R$ is unlikely to be due to chance.

\begin{tabular}{lccc}
\hline & \multicolumn{2}{c}{ Correlation $(R)$} & \\
\cline { 2 - 3 } Product & $\begin{array}{c}\text { Ascending } \\
(\text { LST })\end{array}$ & $\begin{array}{c}\text { Descending } \\
\text { (LST) }\end{array}$ & $p$ value \\
\hline AMSR2 & $0.40(13: 30)$ & $0.50(01: 30)$ & 0.000 \\
ASCAT & $0.41(21: 30)$ & $0.47(09: 30)$ & 0.000 \\
SMAPL3E & $0.65(18: 00)$ & $0.65(06: 00)$ & 0.643 \\
SMOS & $0.49(06: 00)$ & $0.48(18: 00)$ & 0.271 \\
\hline
\end{tabular}

AMSR2, +0.10 for ASCAT, +0.07 for SMAPL3E, +0.17 for SMOS, and +0.11 for ESA-CCI (Fig. 3a). The improvements are probably mainly because the SWI filter reduces the impact of random errors and potential differences between ascending and descending overpasses (Su et al., 2015; Bogoslovskiy et al., 2015). Additionally, since the SWI filter simulates the slower variability of soil moisture at deeper layers (Wagner et al., 1999; Albergel et al., 2008; Brocca et al., 2010a), it improves the consistency between the in situ measurements at $5 \mathrm{~cm}$ depth and the microwave signals, which often have a penetration depth of just $1-2 \mathrm{~cm}$ depending on the observation frequency and the land surface conditions (Long and Ulaby, 2015; Shellito et al., 2016a; Rondinelli et al., 2015; Lv et al., 2018). Our results suggests that previous near-surface soil moisture product assessments (e.g., Zhang et al., 2017; Karthikeyan et al., 2017a; Cui et al., 2018; Al-Yaari et al., 2019; Ma et al., 2019), which generally did not use smoothing filters, may have underestimated the true skill of the products.

\subsection{What is the relative performance of the single-sensor satellite products?}

Among the four single-sensor products with SWI filter

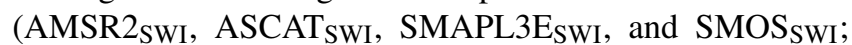
Table 1), SMAPL3E $\mathrm{E}_{S w I}$ performed best in terms of median $R, R_{\mathrm{lo}}$, and $R_{\mathrm{hi}}$ by a wide margin (Figs. 3a and 4 ), in agreement with previous studies using triple collocation (Chen et al., 2018) and in situ measurements from the USA (Karthikeyan et al., 2017a; Zhang et al., 2017; Cui et al., 2018; Al-Yaari et al., 2019), the Tibetan Plateau (Chen et al., 2017), the Iberian Peninsula (Cui et al., 2018), and across the globe (Al-Yaari et al., 2017; Kim et al., 2018; Ma et al., 2019). The good performance of SMAPL3 $\mathrm{E}_{\mathrm{SWI}}$ is likely attributable to the deeper ground penetration of L-band signals (Lv et al., 2018), the sensor's higher radiometric accuracy (Entekhabi et al., 2010a), and the application of an RFI mitigation algorithm (Piepmeier et al., 2014). SMOS SWI is also an L-band product, while the AMSR2 2 wi product used here was derived from X-band observations, which have a shallower penetration depth (Long and Ulaby, 2015).

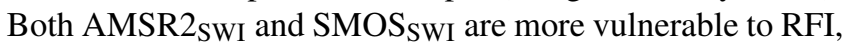
which may have reduced their overall performance (Njoku et al., 2005; Oliva et al., 2012). The active-microwave-based ASCAT $_{\text {SWI }}$ performed significantly better in terms of highfrequency than low-frequency fluctuations (Fig. 4), likely due to the presence of seasonal vegetation-related biases (Wagner et al., 2013). ASCAT SWI $_{\text {showed a relatively small }}$ spread in $R_{\mathrm{hi}}$ values (Fig. $4 \mathrm{~b}$ ), although it showed the largest spread in $R$ and $R_{\text {lo }}$ values not just among the single-sensor products but among all products (Figs. 3a and 4a).

All single-sensor satellite products achieved lower $R$ values in cold climates (Figs. 2 and 3b), in agreement with other global evaluations using ISMN data (Kim et al., 2018; AlYaari et al., 2019; Zhang et al., 2019; Ma et al., 2019), and previously attributed to the confounding influence of dense vegetation cover (de Rosnay et al., 2006; Gruhier et al., 2008; Dorigo et al., 2010), highly organic soils (Zhang et al., 2019), and standing water (Ye et al., 2015; Du et al., 2018) on soil moisture retrievals. However, since the models also tend to exhibit lower $R$ values in cold regions (Fig. 3b), it could also be that the in situ measurements are of lower quality or less representative of satellite footprints or model grid cells, or that our procedure to screen for frozen or snow-covered soils is imperfect. AMSR2 and particularly AMSR2 2 SwI performed noticeably better in terms of $R$ in arid climates (Figs. 2 and 3b), as reported in previous studies (Wu et al., 2016; Cho et al., 2017), and likely due to the availability of coincident Ka-band brightness temperature observations which are used as input to the LPRM retrieval algorithm (Parinussa et al., 2011). AMSR2 and SMOS (with and without SWI filter) showed markedly lower $R$ values for sites with mean leaf area index $>2 \mathrm{~m}^{2} \mathrm{~m}^{-2}$ (Fig. 3c), confirming that their retrievals are affected by dense vegetation cover (AlYaari et al., 2014; Wu et al., 2016; Cui et al., 2018). Most satellite products performed worse in terms of $R$ in areas of steep terrain (Fig. 3d), consistent with previous evaluations (Paulik et al., 2014; Karthikeyan et al., 2017a; Ma et al., 2019), and attributed to the confounding effects of relief on the upwelling microwave brightness temperature observed by the radiometer (Mialon et al., 2008; Pulvirenti et al., 2011; Guo et al., 2011).

\subsection{How do the multi-sensor merged satellite products perform?}

The multi-sensor merged product MeMo (based on AMSR2 ${ }_{S W I}$, SMAPL3E SWI $_{\text {, and SMOS }}$ SWI performed better than the four single-sensor products for all three metrics ( $R, R_{\mathrm{lo}}$, and $R_{\mathrm{hi}}$; Figs. 3a and 4; Table 1 ). These results highlight the value of multi-sensor merging techniques, in line with prior studies that merged satellite retrievals (Gruber et al., 2017; Kim et al., 2018), model outputs (Guo et al., 

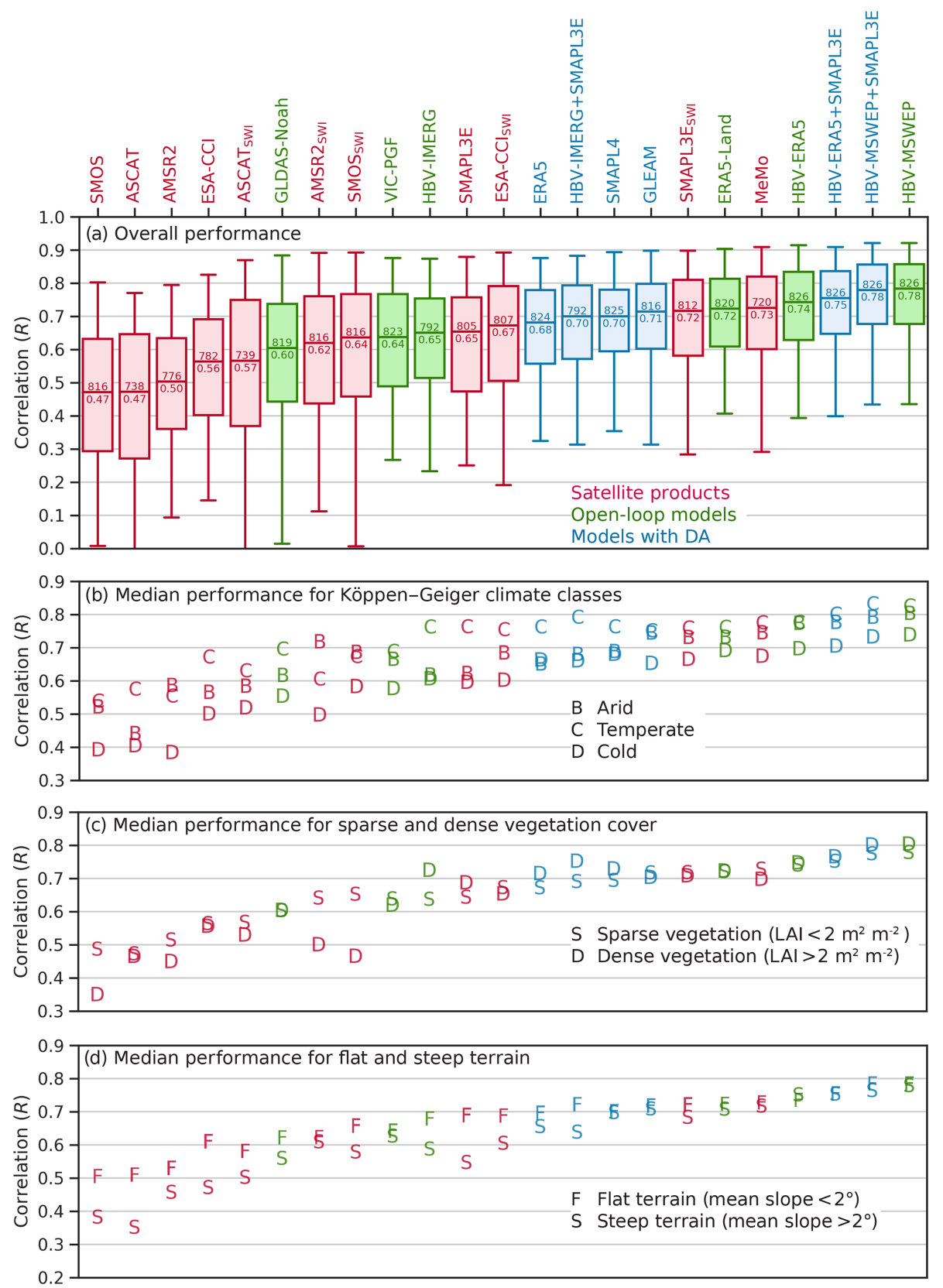

Figure 3. (a) Performance of the soil moisture products in terms of 3-hourly Pearson correlation $(R)$. The products were sorted in ascending order of median $R$. Outliers are not shown. The number above the median line in each box represents the number of sites with $R$ values, and the number below the median line represents the median $R$ value. Also shown are median $R$ values for different (b) major Köppen-Geiger climate classes, (c) mean leaf area index (LAI) values, and (d) mean topographic slopes.

2007; Liu and Xie, 2013; Cammalleri et al., 2015), and satellite retrievals with model outputs (Yilmaz et al., 2012; Anderson et al., 2012; Tobin et al., 2019; Vergopolan et al., 2020). However, MeMo performed only marginally better in terms of median $R$ than the best-performing single-sensor product SMAPL3E $E_{S W I}$ (which was incorporated in MeMo; Fig. 3a). The most likely reason for this is that triple collocation-based merging techniques rely on several assumptions (linearity, stationarity, error orthogonality, and zero cross-correlation), which are generally difficult to fully satisfy in practice, affecting the optimality of the merging procedure (Yilmaz and Crow, 2014; Gruber et al., 2016).

Additionally, MeMo performed better than the multi-

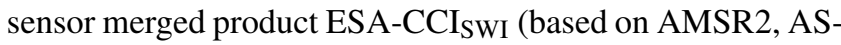
CAT, and SMOS) for all three metrics (Figs. 3a and 4). MeMo performed better in terms of $R$ at $68 \%$ of the sites, 

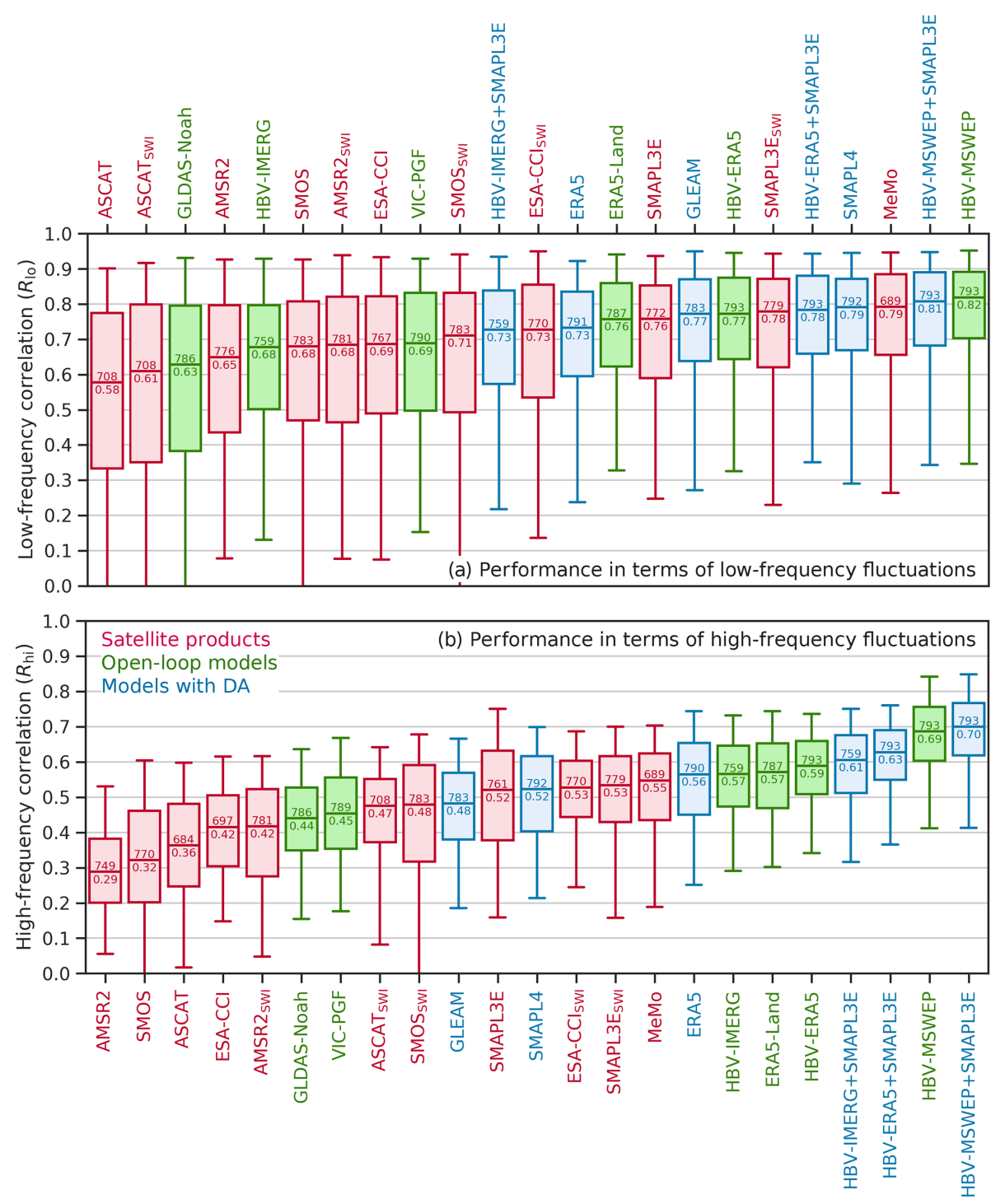

Figure 4. Performance of the soil moisture products in terms of 3-hourly Pearson correlation for (a) low-frequency fluctuations $\left(R_{\mathrm{lo}}\right)$ and (b) high-frequency fluctuations $\left(R_{\mathrm{hi}}\right)$. The products were sorted in ascending order of the median. The number above the median line in each box represents the number of sites with $R_{\mathrm{lo}}$ or $R_{\mathrm{hi}}$ values, and the number below the median line represents the median $R_{\mathrm{lo}}$ or $R_{\mathrm{hi}}$ value. Outliers are not shown.

and performed particularly well across the central Rocky

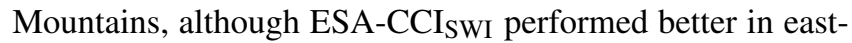
ern Europe (Fig. 5). The two products performed similarly in terms of high-frequency fluctuations (median $R_{\mathrm{hi}}$ of 0.55 for

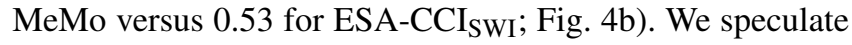
that the better overall performance of MeMo compared to

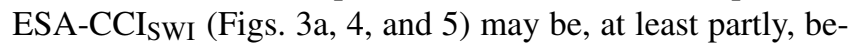
cause ESA-CCISWI incorporates ASCAT, which performed less well in the present evaluation, whereas MeMo incorporates SMAPL3E $E_{S W I}$, which performed best among the single-sensor products (Figs. 3a and 4).

\subsection{What is the relative performance of the open-loop models?}

The ranking of the six open-loop models in terms of median $R$ (from best to worst) was (i) HBV-MSWEP, (ii) HBVERA5, (iii) ERA5-Land, (iv) HBV-IMERG, (v) VIC-PGF, and (vi) GLDAS-Noah (Fig. 3a; Table 1). The models were forced with precipitation from, respectively, (i) the gauge-, satellite-, and reanalysis-based MSWEP V2.4 (Beck et al., 2017b, 2019b); (ii) and (iii) the ERA5 reanalysis (Hersbach et al., 2020); (iv) the satellite-based IMERGHHE V06 (Huffman et al., 2014, 2018); (v) the gauge- and reanalysis-based PGF (Sheffield et al., 2006); and (vi) the gauge- and satellitebased GPCP V1.3 Daily Analysis (Huffman et al., 2001). 

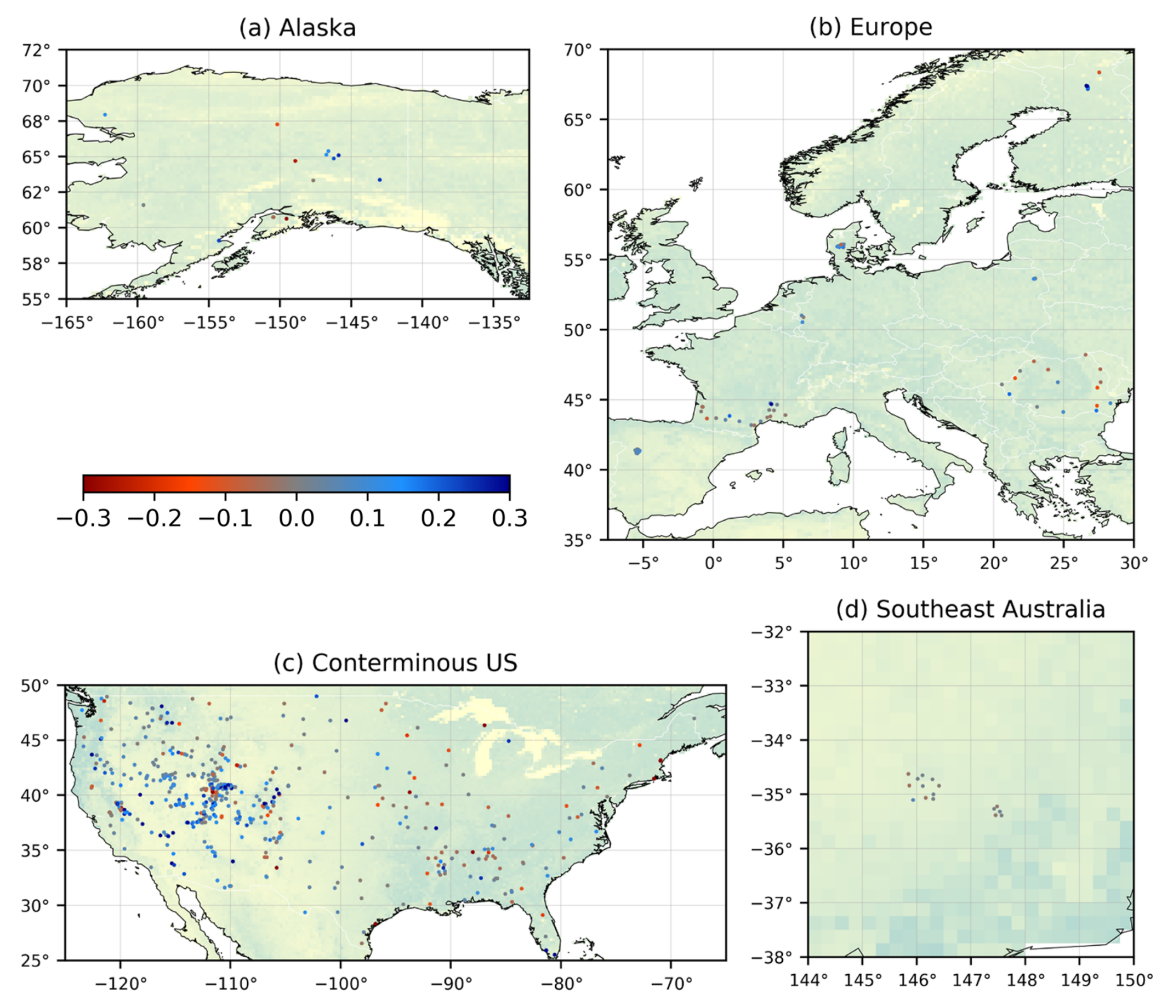

Figure 5. Three-hourly Pearson correlations $(R)$ obtained by MeMo minus those obtained by ESA-CCI. Blue indicates that MeMo performs better, whereas red indicates that ESA-CCI performs better. A map of long-term mean LAI (Baret et al., 2016) is plotted in the background.

This order matches the overall performance ranking of precipitation datasets in a comprehensive evaluation over the conterminous USA carried out by Beck et al. (2019a). Furthermore, the performance of HBV-ERA5 did not depend on the terrain slope, while HBV-IMERG performed worse in steep terrain (Fig. 3d), which is also consistent with the evaluation of Beck et al. (2019a). HBV-IMERG performed worse for low-frequency than for high-frequency fluctuations (Fig. 4), which likely reflects the presence of seasonal biases in IMERG (Beck et al., 2017c; Wang and Yong, 2020). Overall, these results confirm that precipitation is by far the most important determinant of soil moisture simulation performance (Gottschalck et al., 2005; Liu et al., 2011; Beck et al., 2017c; Dong et al., 2019; Chen and Yuan, 2020). The superior performance of MSWEP is primarily attributable to the inclusion of daily gauge observations (Beck et al., 2019b).

Among the three soil moisture products derived from ERA5 precipitation (ERA5, ERA5-Land, and HBVERA5) and among the three products forced with daily gauge-corrected precipitation (GLEAM, HBVMSWEP+SMAPL3E, and SMAPL4; Table 1), the ones based on HBV performed better overall in terms of all three metrics ( $R, R_{\mathrm{lo}}$, and $R_{\mathrm{hi}}$; Figs. 3a and 4 ). This demonstrates that soil moisture estimates from complex data-intensive models (H-TESSEL underlying ERA5 and ERA5-Land, GLEAM, and the NASA Catchment model underlying
SMAPL4) are not necessarily more accurate than those from relatively simple, calibrated models (HBV). This is in line with several previous multi-model evaluations focusing on soil moisture (e.g., Guswa et al., 2002; Cammalleri et al., 2015; Orth et al., 2015), the surface energy balance (e.g., Best et al., 2015), evaporation (e.g., McCabe et al., 2016), runoff (e.g., Beck et al., 2017a), and river discharge (e.g., Gharari et al., 2020).

\subsection{How do the models with satellite data assimilation perform?}

The performance ranking of the models with satellite data assimilation in terms of median $R$ (from best to worst) was HBV-MSWEP+SMAPL3E, HBV-ERA5+SMAPL3E, GLEAM, SMAPL4, HBV-IMERG+SMAPL3E, and ERA5 (Fig. 3a; Table 1). The assimilation of SMAPL3E retrievals resulted in a substantial improvement in median $R$ of +0.06 for HBV-IMERG, a minor improvement of +0.01 for HBVERA5, and no change for HBV-MSWEP (Fig. 3a). Improvements in $R$ were obtained for $90 \%, 65 \%$, and $56 \%$ of the sites for HBV-IMERG, HBV-ERA5, and HBV-MSWEP, respectively. For HBV-IMERG, the greatest improvements were found over the central Rocky Mountains (Fig. 6), where IMERG performs relatively poorly (Beck et al., 2019a). Overall, these results suggest that data assimilation provides greater benefits when the precipitation forcing is more uncer- 
tain. Since rain gauge observations are not available over the large majority of the globe (Kidd et al., 2017), we expect data assimilation to provide significant added value at the global scale, as also concluded by Bolten et al. (2010), Dong et al. (2019), and Tian et al. (2019). The lack of improvement for HBV-ERA5+SMAPL3E and HBV-MSWEP+SMAPL3E suggests that the gain parameter $G$ (Eq. 3), which quantifies the relative quality of the satellite and model soil moisture estimates, can be refined further.

The ERA5 reanalysis, which assimilates ASCAT soil moisture (Hersbach et al., 2020), obtained a lower overall performance (median $R=0.68$ ) than the open-loop models ERA5-Land (median $R=0.72$ ) and HBV-ERA5 (median $R=0.74$ ), which were both forced with ERA5 precipitation (Fig. 3a). This suggests that assimilating satellite soil moisture estimates (ERA5) was less beneficial than either increasing the model resolution (ERA5-Land) or improving the soil moisture simulation efficiency (HBV). In line with these results, Muñoz Sabater et al. (2019) found that the joint assimilation of ASCAT soil moisture retrievals and SMOS brightness temperatures into an experimental version of the Integrated Forecast System (IFS) model underlying ERA5 did not improve the soil moisture simulations. They attributed this to the adverse impact of simultaneously assimilated screen-level temperature and relative humidity observations on the soil moisture estimates.

In line with our results for HBV-MSWEP+SMAPL3E, Kumar et al. (2014) did not obtain improved soil moisture estimates after the assimilation of ESA-CCI and AMSR-E retrievals into Noah forced with highly accurate NLDAS2 meteorological data for the conterminous USA. Conversely, several other studies obtained substantial performance improvements after data assimilation despite the use of highquality precipitation forcings (Liu et al., 2011; Koster et al., 2018; Tian et al., 2019). We suspect that this discrepancy might reflect the lower performance of their open-loop models compared to ours. Using different (but overlapping) in situ datasets, Koster et al. (2018) and Tian et al. (2019) obtained mean daily open-loop $R$ values of 0.64 and 0.59 , respectively, while we obtained a mean daily open-loop $R$ of 0.75 (slightly lower than the 3-hourly median value shown in Fig. 3a). Overall, it appears that the benefits of data assimilation are greater for models that exhibit structural or parameterization deficiencies.

\subsection{What is the impact of model calibration?}

Among the models evaluated in this study, only HBV and the NASA Catchment model underlying SMAPL4 have been calibrated against in situ soil moisture measurements, although only a single parameter out of more than 100 was calibrated for the Catchment model (Reichle et al., 2019b). HBV-ERA5, HBV-IMERG, and HBV-MSWEP with calibrated parameters obtained median $R$ values of $0.74,0.65$, and 0.78 , respectively (Fig. 3a), whereas the same three mod- els with randomly generated (uncalibrated) parameters obtained mean median $R$ values of $0.59,0.53$, and 0.62 , respectively (standard deviations $0.17,0.16$, and 0.16 , respectively; data not shown). The calibration thus resulted in mean increases in median $R$ of $+0.15,+0.12$, and +0.16 , respectively, for the three models, which represent substantial improvements in performance. These results are in line with previous studies calibrating different models using soil moisture from in situ sensors (e.g., Koren et al., 2008; Shellito et al., 2016b; Thorstensen et al., 2016; Reichle et al., 2019b) or remote sensing (e.g., Zhang et al., 2011; Wanders et al., 2014; López López et al., 2016; Koster et al., 2018).

The mean improvements in median $R$ obtained for HBVERA5, HBV-IMERG, and HBV-MSWEP after calibration $(+0.15,+0.12$, and +0.16 , respectively) were significantly greater than the improvements obtained for the same three models after satellite data assimilation $(+0.01,+0.06$, and 0.00, respectively; Fig. 3a; Sect. 3.6), which suggests that model calibration results in more benefit overall than data assimilation. Additionally, model calibration benefits regions with both sparse and dense rain gauge networks, whereas data assimilation mainly benefits regions with sparse rain gauge networks (Sect. 3.6). Conversely, only data assimilation is capable of ameliorating potential deficiencies in the meteorological forcing data (e.g., undetected precipitation).

Our calibration approach was relatively simple and yielded only a single spatially uniform parameter set (Sect. 2.3). Previous studies focusing on runoff have demonstrated the value of more sophisticated calibration approaches yielding ensembles of parameters that vary according to climate and landscape characteristics (Samaniego et al., 2010; Beck et al., 2016, 2020). Whether these approaches have value for soil moisture estimation as well warrants further investigation. It should be noted, however, that many current models have rigid structures, insufficient free parameters, and/or a high computational cost which makes them less amenable to calibration (Mendoza et al., 2015). Moreover, the validity of calibrated parameters may be compromised when the model is subjected to climate conditions it has never experienced before (Knutti, 2008). Care should also be taken that calibration of one aspect of the model does not degrade another aspect and that we get "the right answers for the right reasons" (Kirchner, 2006).

\subsection{How do the major product categories compare?}

The median $R \pm$ interquartile range across all sites and products in each category was $0.53 \pm 0.32$ for the satellite soil moisture products without SWI filter, $0.66 \pm 0.30$ for the satellite soil moisture products with SWI filter including MeMo, $0.69 \pm 0.25$ for the open-loop models, and $0.72 \pm 0.22$ for the models with satellite data assimilation (Fig. 3a; Table 1). The satellite products thus provided the least reliable soil moisture estimates and exhibited the largest regional performance differences on average, whereas the models with 

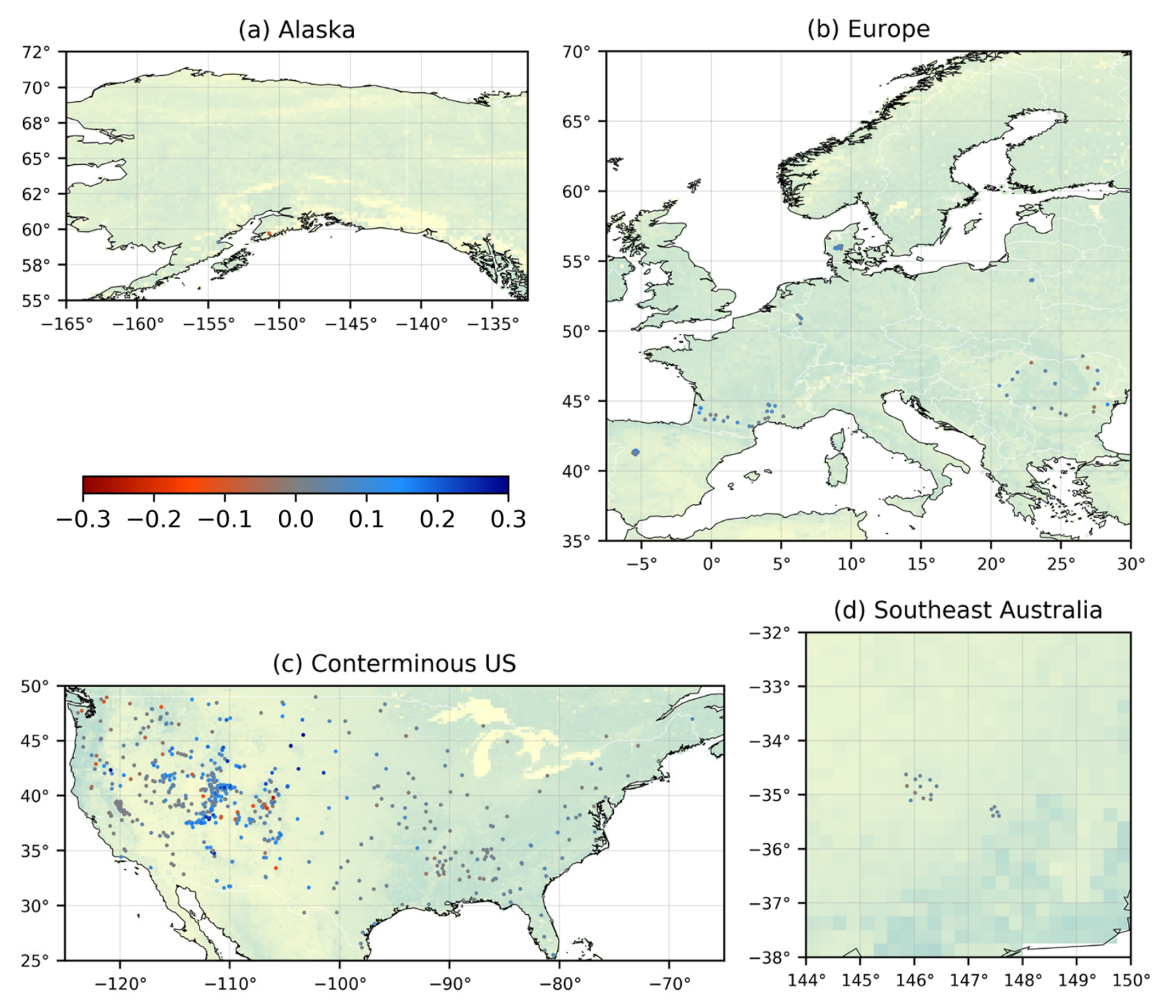

Figure 6. Three-hourly Pearson correlations $(R)$ obtained by HBV-IMERG+SMAPL3E minus those obtained by HBV-IMERG. Blue indicates improved performance after data assimilation, whereas red indicates degraded performance after data assimilation. The sites in Alaska and Finland are not shown as IMERG does not cover high latitudes. A map of long-term mean LAI (Baret et al., 2016) is plotted in the background.

satellite data assimilation provided the most reliable soil moisture estimates and exhibited the smallest regional performance differences on average. Our performance ranking of the major product categories is consistent with previous studies for the conterminous USA (Liu et al., 2011; Kumar et al., 2014; Fang et al., 2016; Dong et al., 2020), Europe (Naz et al., 2019), and the globe (Albergel et al., 2012; Tian et al., 2019; Dong et al., 2019). It should be kept in mind, however, that these studies, including the present one, used in situ soil moisture measurements from regions with dense rain gauge networks and hence likely overestimate model performance (Dong et al., 2019).

The large spread in performance across the satellite products reflects the large number of factors that affect soil moisture retrieval, including, among others, vegetation cover, surface roughness, soil composition, diurnal variations in land surface conditions, and RFI (Zhang and Zhou, 2016; Karthikeyan et al., 2017b). The spread in performance across the open-loop models is lower as it depends primarily on the precipitation data quality, which, in turn, depends mostly on a combination of gauge network density and prevailing precipitation type (convective versus frontal; Gottschalck et al., 2005; Liu et al., 2011; Beck et al., 2017c; Dong et al., 2019). The smaller spread in performance across the models with satellite data assimilation is due to the fact that individual errors in satellite retrievals and model estimates are canceled out, to a certain degree, when they are combined, confirming the effectiveness of the data assimilation procedures (Moradkhani, 2008; Liu et al., 2012; Reichle et al., 2017).

\subsection{To what extent are our results generalizable to other regions?}

The large majority $(98 \%)$ of the in situ soil moisture measurements used as reference in the current study was from dense monitoring networks in the USA and Europe (Fig. 2); therefore, our results will be most applicable to these regions. We speculate that our results for the models (with and without data assimilation; Figs. 3, 4, and 6) apply to other regions with dense rain gauge networks and broadly similar climates (e.g., parts of China and Australia and other parts of Europe; Kidd et al., 2017). The calibrated models (HBV and the NASA Catchment model underlying SMAPL4) may, however, perform slightly worse in regions with climatic and physiographic conditions dissimilar to the in situ sensors used for calibration (but likely still better than the uncalibrated models). In sparsely gauged areas the four model products based on precipitation forcings that incorporate daily gauge observations (GLEAM, HBV-MSWEP, HBV- 
MSWEP+SMAPL3E, and SMAPL4; Table 1) will inevitably exhibit lower performance (but not necessarily lower than the other model products). In convection-dominated regions models driven by precipitation from satellite datasets such as IMERG may well outperform those driven by precipitation from reanalyses such as ERA5 (Massari et al., 2017; Beck et al., 2017c, 2019b). Conversely, in mountainous and snowdominated regions models driven by precipitation from reanalyses are likely to outperform those driven by precipitation from satellites (Ebert et al., 2007; Beck et al., 2019b, a).

Our results for the satellite soil moisture products may be less generalizable, given the large spread in performance across different regions and products revealed in the current study (Figs. 3 and 4) and in previous quasi-global studies using triple collocation (Al-Yaari et al., 2014; Chen et al., 2018; Miyaoka et al., 2017). Outside developed regions we expect the lower prevalence of RFI to lead to more reliable retrievals for those satellite products susceptible to it (Njoku et al., 2005; Oliva et al., 2012; Aksoy and Johnson, 2013; Ticconi et al., 2017). At low latitudes the lower satellite revisit frequency will inevitably increase the sampling uncertainty and reduce the overall value of satellite products relative to models. In tropical forest regions passive products often do not provide soil moisture retrievals, and when they do, the retrievals are typically less reliable than those from active products due to the dense vegetation cover (Al-Yaari et al., 2014; Chen et al., 2018; Miyaoka et al., 2017; Kim et al., 2018). Shedding more light on the strengths and weaknesses of soil moisture products in regions without dense measurement networks - for example using independent soil moisture products (Chen et al., 2018; Dong et al., 2019) or by expanding measurement networks (Kang et al., 2016; Singh et al., 2019) - should be a key priority for future research (Ochsner et al., 2013; Myeni et al., 2019).

\section{Conclusions}

To shed light on the advantages and disadvantages of different soil moisture products and on the merit of various technological and methodological innovations, we evaluated 18 state-of-the-art (sub-)daily (quasi-)global near-surface soil moisture products using in situ measurements from 826 sensors located primarily in the USA and Europe. Our main findings related to the nine questions posed in the introduction can be summarized as follows:

1. Local night retrievals from descending overpasses were more reliable overall for AMSR2, whereas local morning retrievals from descending overpasses were more reliable overall for ASCAT. The ascending and descending retrievals of SMAPL3E and SMOS performed similarly.
2. Application of the SWI smoothing filter resulted in improved performance for all satellite products. Previous near-surface soil moisture product assessments generally did not apply smoothing filters and therefore may have underestimated the true skill of the products.

3. SMAPL3E $E_{S W I}$ performed best overall among the four single-sensor satellite products with SWI filter. ASCAT $_{\text {SWI }}$ performed markedly better in terms of highfrequency than low-frequency fluctuations. All satellite products tended to perform worse in cold climates.

4. The multi-sensor merged satellite product MeMo performed best among the satellite products, highlighting the value of multi-sensor merging techniques. MeMo also outperformed the multi-sensor merged satellite product ESA-CCI ${ }_{S W I}$, likely due to the inclusion of SMAPL3E

5. The performance of the open-loop models depended primarily on the precipitation data quality. The superior performance of HBV-MSWEP is due to the calibration of HBV and the daily gauge corrections of MSWEP. Soil moisture simulation performance did not improve with model complexity.

6. In the absence of model structural or parameterization deficiencies, satellite data assimilation yields substantial performance improvements mainly when the precipitation forcing is of relatively low quality. This suggests that data assimilation provides significant benefits at the global scale.

7. The calibration of HBV against in situ soil moisture measurements resulted in substantial performance improvements. The improvement due to model calibration tends to exceed the improvement due to satellite data assimilation and is not limited to regions of low-quality precipitation data.

8. The satellite products provided the least reliable soil moisture estimates and exhibited the largest regional performance differences on average, whereas the models with satellite data assimilation provided the most reliable soil moisture estimates and exhibited the smallest regional performance differences on average.

9. We speculate that our results for the models (with and without data assimilation) apply to other regions with dense rain gauge networks and broadly similar climates. Our results for the satellite products may be less generalizable due to the large number of factors that affect retrievals. 
Appendix A: In situ soil moisture measurement networks

Table A1 lists the measurement networks from which we have used in situ soil moisture data.

Table A1. The measurement networks from which we have used in situ soil moisture data.

\begin{tabular}{|c|c|}
\hline Network & Reference(s) or website \\
\hline ARM & $\begin{array}{l}\text { http://www.arm.gov } \\
\text { (last access: August 2019) }\end{array}$ \\
\hline BIEBRZA & $\begin{array}{l}\text { http://www.igik.edu.pl } \\
\text { (last access: August 2019) }\end{array}$ \\
\hline BNZ-LTER & Van Cleve et al. (2015) \\
\hline COSMOS & Zreda et al. $(2008,2012)$ \\
\hline CTP & Yang et al. (2013) \\
\hline DAHRA & Tagesson et al. (2015) \\
\hline FMI & $\begin{array}{l}\text { http://fmiarc.fmi.fi } \\
\text { (last access: August 2019) }\end{array}$ \\
\hline FR & $\begin{array}{l}\text { http://www.inrae.fr } \\
\text { (last access: August 2019) }\end{array}$ \\
\hline HOBE & Kang et al. (2014), Jin et al. (2014) \\
\hline HYDROL-NET & Morbidelli et al. (2014) \\
\hline iRON & Osenga et al. (2019) \\
\hline LAB-net & Mattar et al. (2014) \\
\hline MySMNet & Kang et al. (2016) \\
\hline ORACLE & $\begin{array}{l}\text { https://gisoracle.inrae.fr } \\
\text { (last access: August 2019) }\end{array}$ \\
\hline OZNET & Smith et al. (2012) \\
\hline REMEDHUS & $\begin{array}{l}\text { http://campus.usal.es/ hidrus/ } \\
\text { (last access: August 2019) }\end{array}$ \\
\hline RISMA & Ojo et al. (2015) \\
\hline RSMN & $\begin{array}{l}\text { http://assimo.meteoromania.ro } \\
\text { (last access: August 2019) }\end{array}$ \\
\hline SCAN & $\begin{array}{l}\text { http://www.wcc.nrcs.usda.gov } \\
\text { (last access: August 2019) }\end{array}$ \\
\hline SMOSMANIA & Calvet et al. (2007), Albergel et al. (2008) \\
\hline SNOTEL & $\begin{array}{l}\text { http://www.wcc.nrcs.usda.gov } \\
\text { (last access: August 2019) }\end{array}$ \\
\hline SOILSCAPE & Moghaddam et al. (2010, 2016) \\
\hline SWEX & Marczewski et al. (2010) \\
\hline TERENO & Zacharias et al. (2011) \\
\hline UDC & Loew et al. (2009) \\
\hline USCRN & Bell et al. (2013) \\
\hline WSMN & Petropoulos and McCalmont (2017) \\
\hline
\end{tabular}


Data availability. The ISMN database is available via https:// ismn.geo.tuwien.ac.at (last access: August 2019); AMSR2 is available via https://hydro1.gesdisc.eosdis.nasa.gov/data/WAOB/ LPRM_AMSR2_DS_D_SOILM3.001/ (last access: August 2019); ASCAT is available via https://navigator.eumetsat.int (last access: August 2019); SMAPL3E is available via https://n5eil01u. ecs.nsidc.org/SMAP/SPL3SMP_E.003/ (last access: August 2019); SMOS is available via ftp://smos-diss.eo.esa.int/SMOS/L2SM/ MIR_SMUDP2_nc/ (last access: August 2019); ESA-CCI is available via https://www.esa-soilmoisture-cci.org (last access: August 2019); ERA5 and ERA5-Land are available via https:// cds.climate.copernicus.eu (last access: August 2019); GLDASNoah is available via https://doi.org/10.5067/E7TYRXPJKWOQ (Beaudoing and Rodell, 2020); VIC-PGF is available via http: //hydrology.princeton.edu/data/hexg/GDFC/ (last access: August 2019); GLEAM is available via https://www.gleam.eu/ (last access: August 2019); SMAPL4 is available via https://n5eil01u. ecs.nsidc.org/SMAP/SPL4SMAU.004/ (last access: August 2019); MeMo and the HBV models are available upon request from the first author; MSWEP is available via http://www.gloh2o. org/mswep (last access: August 2019); IMERG is available via https://doi.org/10.5067/GPM/IMERG/3B-HH-L/06 (Huffman et al., 2019); the Köppen-Geiger map is available via http://www. gloh2o.org/koppen (last access: August 2019); the Copernicus LAI dataset is available via https://land.copernicus.eu/global/products/ lai (last access: August 2019); and the MERIT DEM is available via http://hydro.iis.u-tokyo.ac.jp/ yamadai/MERIT_DEM/ (last access: August 2019).

Supplement. The supplement related to this article is available online at: https://doi.org/10.5194/hess-25-17-2021-supplement.

Author contributions. HEB conceived, designed, and performed the analysis and took the lead in writing the paper. EFW was responsible for funding acquisition. All co-authors provided critical feedback and contributed to the writing.

Competing interests. The authors declare that they have no conflict of interest.

Acknowledgements. We are grateful to the numerous contributors to the ISMN archive. The soil moisture product developers are thanked for producing and making available their products. We thank the editor, Christian Massari, Korbin Nelson, Clément Albergel, and one anonymous reviewer for their constructive comments which helped us to improve the article.

Financial support. This research has been supported by the U.S. Army Corps of Engineers' International Center for Integrated Water Resources Management (ICIWaRM), National Natural Science Foundation of China (grant no. 41850410492), NASA Soil Moisture Cal/Val Activities (grant no. NNX14AH92G), NOAA's “Modernizing Observation Operator and Error Assessment for Assimilating In-situ and Remotely Sensed Snow/Soil Moisture Mea- surements into NWM" project (grant no. NA19OAR4590199), the NASA SMAP Science Team, European Research Council (ERC) DRY-2-DRY project (grant no. 715254), the Belgian Science Policy Office (BELSPO) STEREO III ALBERI project (grant no. SR/00/373), the ESA CCI program, and ESA's IDEAS+ and QA4EO projects.

Review statement. This paper was edited by Harrie-Jan Hendricks Franssen and reviewed by Christian Massari, Clément Albergel, and one anonymous referee.

\section{References}

Aksoy, M. and Johnson, J. T.: A study of SMOS RFI over North America, IEEE Geosci. Remote S., 10, 515-519, 2013.

Albergel, C., Rüdiger, C., Pellarin, T., Calvet, J.-C., Fritz, N., Froissard, F., Suquia, D., Petitpa, A., Piguet, B., and Martin, E.: From near-surface to root-zone soil moisture using an exponential filter: an assessment of the method based on in-situ observations and model simulations, Hydrol. Earth Syst. Sci., 12, 1323-1337, https://doi.org/10.5194/hess-12-1323-2008, 2008.

Albergel, C., Rüdiger, C., Carrer, D., Calvet, J.-C., Fritz, N., Naeimi, V., Bartalis, Z., and Hasenauer, S.: An evaluation of ASCAT surface soil moisture products with in-situ observations in Southwestern France, Hydrol. Earth Syst. Sci., 13, 115-124, https://doi.org/10.5194/hess-13-115-2009, 2009.

Albergel, C., de Rosnay, P., Gruhier, C., Muñoz-Sabatera, J., Hasenauer, S., Isaksen, L., Kerr, Y., and Wagner, W.: Evaluation of remotely sensed and modelled soil moisture products using global ground-based in situ observations, Remote Sens. Environ., 118, 215-226, https://doi.org/10.1016/j.rse.2011.11.017, 2012.

Al-Yaari, A., Wigneron, J.-P., Ducharne, A., Kerr, Y., de Rosnay, P., de Jeu, R., Govind, A., Al Bitar, A., Albergel, C., MuñozSabater, J., Richaume, P., and Mialon, A.: Global-scale evaluation of two satellite-based passive microwave soil moisture datasets (SMOS and AMSR-E) with respect to Land Data Assimilation System estimates, Remote Sens. Environ., 149, 181-195, https://doi.org/10.1016/j.rse.2014.04.006, 2014.

Al-Yaari, A., Wigneron, J.-P., Kerr, Y., Rodriguez-Fernandez, N., O’Neill, P. E., Jackson, T. J., De Lannoy, G. J. M., Al Bitar, A., Mialon, A., Richaume, P., Walker, J. P., Mahmoodi, A., and Yueh, S.: Evaluating soil moisture retrievals from ESA's SMOS and NASA's SMAP brightness temperature datasets, Remote Sens. Environ., 193, 257-273, https://doi.org/10.1016/j.rse.2017.03.010, 2017.

Al-Yaari, A., Wigneron, J.-P., Dorigo, W., Colliander, A., Pellarin, T., Hahn, S., Mialon, A., Richaume, P., FernandezMoran, R., Fan, L., Kerr, Y., and De Lannoy, G.: Assessment and inter-comparison of recently developed/reprocessed microwave satellite soil moisture products using ISMN groundbased measurements, Remote Sens. Environ., 224, 289-303, https://doi.org/10.1016/j.rse.2019.02.008, 2019.

Anderson, W. B., Zaitchik, B. F., Hain, C. R., Anderson, M. C., Yilmaz, M. T., Mecikalski, J., and Schultz, L.: Towards an integrated soil moisture drought monitor for East Africa, Hydrol. Earth Syst. Sci., 16, 2893-2913, https://doi.org/10.5194/hess-162893-2012, 2012. 
Baret, F., Weiss, M., Verger, A., and Smets, B.: ATBD for LAI, FAPAR and FCOVER from PROBA-V products at $300 \mathrm{~m}$ resolution (GEOV3), INRA - Institut National de la Recherche Agronomique, Paris, France, 2016.

Beaudoing, H. and Rodell, M.: GLDAS Noah Land Surface Model L4 3 hourly $0.25 \times 0.25$ degree V2.1, NASA/GSFC/HSL, Greenbelt, Maryland, USA, Goddard Earth Sciences Data and Information Services Center (GES DISC), https://doi.org/10.5067/E7TYRXPJKWOQ, 2020.

Beck, H. E., de Jeu, R. A. M., Schellekens, J., Van Dijk, A. I. J. M., and Bruijnzeel, L. A.: Improving curve number based storm runoff estimates using soil moisture proxies, IEEE J. Sel. Top. Appl., 2, 250-259, 2009.

Beck, H. E., Bruijnzeel, L. A., van Dijk, A. I. J. M., McVicar, T. R., Scatena, F. N., and Schellekens, J.: The impact of forest regeneration on streamflow in 12 mesoscale humid tropical catchments, Hydrol. Earth Syst. Sci., 17, 2613-2635, https://doi.org/10.5194/hess-17-2613-2013, 2013.

Beck, H. E., van Dijk, A. I. J. M., de Roo, A., Miralles, D. G., McVicar, T. R., Schellekens, J., and Bruijnzeel, L. A.: Globalscale regionalization of hydrologic model parameters, Water Resour. Res., 52, 3599-3622, 2016.

Beck, H. E., van Dijk, A. I. J. M., de Roo, A., Dutra, E., Fink, G., Orth, R., and Schellekens, J.: Global evaluation of runoff from 10 state-of-the-art hydrological models, Hydrol. Earth Syst. Sci., 21, 2881-2903, https://doi.org/10.5194/hess-21-2881-2017, 2017a.

Beck, H. E., van Dijk, A. I. J. M., Levizzani, V., Schellekens, J., Miralles, D. G., Martens, B., and de Roo, A.: MSWEP: 3hourly $0.25^{\circ}$ global gridded precipitation (1979-2015) by merging gauge, satellite, and reanalysis data, Hydrol. Earth Syst. Sci., 21, 589-615, https://doi.org/10.5194/hess-21-589-2017, 2017b.

Beck, H. E., Vergopolan, N., Pan, M., Levizzani, V., van Dijk, A. I. J. M., Weedon, G. P., Brocca, L., Pappenberger, F., Huffman, G. J., and Wood, E. F.: Global-scale evaluation of 22 precipitation datasets using gauge observations and hydrological modeling, Hydrol. Earth Syst. Sci., 21, 6201-6217, https://doi.org/10.5194/hess-21-6201-2017, 2017c.

Beck, H. E., Zimmermann, N. E., McVicar, T. R., Vergopolan, N., Berg, A., and Wood, E. F.: Present and future Köppen-Geiger climate classification maps at $1 \mathrm{~km}$ resolution, Scientific Data, 5, 180214, https://doi.org/10.1038/sdata.2018.214, 2018.

Beck, H. E., Pan, M., Roy, T., Weedon, G. P., Pappenberger, F., van Dijk, A. I. J. M., Huffman, G. J., Adler, R. F., and Wood, E. F.: Daily evaluation of 26 precipitation datasets using Stage-IV gauge-radar data for the CONUS, Hydrol. Earth Syst. Sci., 23, 207-224, https://doi.org/10.5194/hess-23-207-2019, 2019a.

Beck, H. E., Wood, E. F., Pan, M., Fisher, C. K., Miralles, D. M., van Dijk, A. I. J. M., McVicar, T. R., and Adler, R. F.: MSWEP V2 global 3-hourly $0.1^{\circ}$ precipitation: methodology and quantitative assessment, B. Ame. Meteorol. Soc., 100, 473-500, 2019 b.

Beck, H. E., Pan, M., Lin, P., Seibert, J., van Dijk, A. I. J. M., and Wood, E. F.: Global fully distributed parameter regionalization based on observed streamflow from 4229 headwater catchments, J. Geophys. Res.-Atmos., 125, e2019JD031485, https://doi.org/10.1029/2019JD031485, 2020.

Bell, J. E., Palecki, M. A., Baker, C. B., Collins, W. G., Lawrimore, J. H., Leeper, R. D., Hall, M. E., Kochendorfer, J., Meyers, T. P., Wilson, T., and Diamond, H. J.: U.S. climate reference network soil moisture and temperature observations, J. Hydrometeorol., 14, 977-988, 2013.

Bergström, S.: Development and application of a conceptual runoff model for Scandinavian catchments, $\mathrm{PhD}$ thesis, Swedish Meteorological and Hydrological Institute (SMHI), Norköping, Sweden, 1976.

Bergström, S.: The HBV model - its structure and applications, SMHI Reports RH 4, Swedish Meteorological and Hydrological Institute (SMHI), Norrköping, Sweden, 1992.

Best, M. J., Abramowitz, G., Johnson, H. R., Pitman, A. J., Balsamo, G., Boone, A., Cuntz, M., Decharme, B., Dirmeyer, P. A., Dong, J., Ek, M., Guo, Z., Haverd, V., van den Hurk, B. J. J., Nearing, G. S., Pak, B., Peters-Lidard, C., Santanello, J. A., Stevens, L., and Vuichard, N.: The plumbing of land surface models: benchmarking model performance, J. Hydrometeorol., 16, 1425-1442, 2015.

Bierkens, M. F. P.: Global hydrology 2015: state, trends, and directions, Water Resour. Res., 51, 4923-4947, https://doi.org/10.1002/2015WR017173, 2015.

Bindlish, R., Cosh, M. H., Jackson, T. J., Koike, T., Fujii, H., Chan, S. K., Asanuma, J., Berg, A., Bosch, D. D., Caldwell, T., Collins, C. H., McNairn, H., Martinez-Fernandez, J., Prueger, J., Rowlandson, T., Seyfried, M., Starks, P., Thibeault, M., Van Der Velde, R., Walker, J. P., and Coopersmith, E. J.: GCOM-W AMSR2 soil moisture product validation using core validation sites, IEEE J. Sel. Top. Appl. 11, 209-219, 2018.

Bogoslovskiy, N. N., Erin, S. I., Borodina, I. A., and Kizhner, L. I.: Filtration and assimilation of soil moisture satellite data, in: $21 \mathrm{st}$ International Symposium Atmospheric and Ocean Optics: Atmospheric Physics, 22-26 June 2015, Tomsk, Russian Federation, 1411-1415, https://doi.org/10.1117/12.2205957, 2015.

Bolten, J. D., Crow, W. T., Zhan, X., Jackson, T. J., and Reynolds, C. A.: Evaluating the utility of remotely sensed soil moisture retrievals for operational agricultural drought monitoring, IEEE J. Sel. Top. Appl., 3, 57-66, 2010.

Brocca, L., Melone, F., Moramarco, T., Wagner, W., and Hasenauer, S.: ASCAT soil wetness index validation through in situ and modeled soil moisture data in central Italy, Remote Sens. Environ., 114, 2745-2755, 2010a.

Brocca, L., Melone, F., Moramarco, T., Wagner, W., Naeimi, V., Bartalis, Z., and Hasenauer, S.: Improving runoff prediction through the assimilation of the ASCAT soil moisture product, Hydrol. Earth Syst. Sci., 14, 1881-1893, https://doi.org/10.5194/hess-14-1881-2010 2010b.

Brocca, L., Crow, W. T., Ciabatta, L., Massari, C., de Rosnay, P., Enenkel, M., Hahn, S., Amarnath, G., Camici, S., Tarpanelli, A., and Wagner, W.: A review of the applications of ASCAT soil moisture products, IEEE J. Sel. Top. Appl., 10, 2285-2306, 2017.

C3S: ERA5-Land reanalysis, available at: https://cds.climate. copernicus.eu (last access: 24 November 2020), 2019.

Calvet, J., Fritz, N., Froissard, F., Suquia, D., Petitpa, A., and Piguet, B.: In situ soil moisture observations for the CAL/VAL of SMOS: the SMOSMANIA network, in: Proceedings of the IEEE International Geoscience and Remote Sensing Symposium, 2328 July 2007, Barcelona, Spain, 1196-1199, 2007.

Cammalleri, C., Micale, F., and Vogt, J.: On the value of combining different modelled soil moisture products for 
European drought monitoring, J. Hydrol., 525, 547-558, https://doi.org/10.1016/j.jhydrol.2015.04.021, 2015.

Capecchi, V. and Brocca, L.: A simple assimilation method to ingest satellite soil moisture into a limited-area NWP model, Meteorol. Z., 23, 105-121, 2014.

Cenci, L., Laiolo, P., Gabellani, S., Campo, L., Silvestro, F., Delogu, F., Boni, G., and Rudari, R.: Assimilation of H-SAF soil moisture products for flash flood early warning systems. case study: Mediterranean catchments, IEEE J. Sel. Top. Appl., 9, 56345646, 2016.

Champagne, C., Berg, A., Belanger, J., McNairn, H., and De Jeu, R.: Evaluation of soil moisture derived from passive microwave remote sensing over agricultural sites in Canada using groundbased soil moisture monitoring networks, Int. J. Remote Sens., 31, 3669-3690, 2010.

Chan, S. K., Bindlish, R., O’Neill, P., Jackson, T., Njoku, E., Dunbar, S., Chaubell, J., Piepmeier, J., Yueh, S., Entekhabi, D., Colliander, A., Chen, F., Cosh, M. H., Caldwell, T., Walker, J., Berg, A., McNairn, H., Thibeault, M., Martinez-Fernández, J., Uldall, F., Seyfried, M., Bosch, D., Starks, P., Holifield Collins, C., Prueger, J., van der Velde, R., Asanuma, J., Palecki, M., Small, E. E., Zreda, M., Calvet, J., Crow, W. T., and Kerr, Y.: Development and assessment of the SMAP enhanced passive soil moisture product, Remote Sens. Environ., 204, 931-941, https://doi.org/10.1016/j.rse.2017.08.025, 2018.

Chawla, I., Karthikeyan, L., and Mishra, A. K.: A review of remote sensing applications for water security: quantity, quality, and extremes, J. Hydrol., 585, 124826, https://doi.org/10.1016/j.jhydrol.2020.124826, 2020.

Chen, F., Crow, W. T., Bindlish, R., Colliander, A., Burgin, M. S., Asanuma, J., and Aida, K.: Global-scale evaluation of SMAP, SMOS and ASCAT soil moisture products using triple collocation, Remote Sens. Environ., 214, 1-13, https://doi.org/10.1016/j.rse.2018.05.008, 2018.

Chen, M., Shi, W., Xie, P., Silva, V. B. S., Kousky, V. E., Higgins, R. W., and Janowiak, J. E.: Assessing objective techniques for gauge-based analyses of global daily precipitation, J. Geophys. Res.-Atmos., 113, D04110, https://doi.org/10.1029/2007JD009132, 2008.

Chen, Y. and Yuan, H.: Evaluation of nine sub-daily soil moisture model products over China using highresolution in situ observations, J. Hydrol., 588, 125054, https://doi.org/10.1016/j.jhydrol.2020.125054, 2020.

Chen, Y., Yang, K., Qin, J., Cui, Q., Lu, H., La, Z., Han, M., and Tang, W.: Evaluation of SMAP, SMOS, and AMSR2 soil moisture retrievals against observations from two networks on the Tibetan Plateau, J. Geophys. Res.-Atmos., 122, 5780-5792, 2017.

Cho, E., Su, C.-H., Ryu, D., Kim, H., and Choi, M.: Does AMSR2 produce better soil moisture retrievals than AMSRE over Australia?, Remote Sens. Environ., 188, 95-105, https://doi.org/10.1016/j.rse.2016.10.050, 2017.

Crow, W. T., Miralles, D. G., and Cosh, M. H.: A quasi-global evaluation system for satellite-based surface soil moisture retrievals, IEEE T. Geoscie. Remote, 48, 2516-2527, 2010.

Crow, W. T., Berg, A. A., Cosh, M. H., Loew, A., Mohanty, B. P., Panciera, R., de Rosnay, P., Ryu, D., and Walker, J. P.: Upscaling sparse ground-based soil moisture observations for the validation of coarse-resolution satellite soil moisture products, Rev.
Geophys., 50, RG2002, https://doi.org/10.1029/2011RG000372, 2012.

Cui, C., Xu, J., Zeng, J., Chen, K.-S., Bai, X., Lu, H., Chen, Q., and Zhao, T.: Soil moisture mapping from satellites: an intercomparison of SMAP, SMOS, FY3B, AMSR2, and ESA CCI over two dense network regions at different spatial scales, Remote Sens., 10, 33, https://doi.org/10.3390/rs10010033, 2018.

de Rosnay, P., Calvet, J.-C., Kerr, Y., Wigneron, J.-P., Lemaitre, F., Escorihuela, M. J., Muñoz-Sabater, J., Saleh, K., Barrié, J., Bouhours, G., Coret, L., Cherel, G., Dedieu, G., Durbe, R., Fritz, N., Froissard, F., Hoedjes, J., Kruszewski, A., Lavenu, F., Suquia, D., and Waldteufel, P.: SMOSREX: a long term field campaign experiment for soil moisture and land surface processes remote sensing, Remote Sens. Environ., 102, 377-389, 2006.

Dharssi, I., Bovis, K. J., Macpherson, B., and Jones, C. P.: Operational assimilation of ASCAT surface soil wetness at the Met Office, Hydrol. Earth Syst. Sci., 15, 2729-2746, https://doi.org/10.5194/hess-15-2729-2011, 2011.

Dong, J., Crow, W., Reichle, R., Liu, Q., Lei, F., and Cosh, M. H.: A global assessment of added value in the SMAP Level 4 soil moisture product relative to its baseline land surface model, Geophys. Res. Lett., 46, 6604-6613, 2019.

Dong, J., Crow, W. T., Tobin, K. J., Cosh, M. H., Bosch, D. D., Starks, P. J., Seyfried, M., and Collins, C. H.: Comparison of microwave remote sensing and land surface modeling for surface soil moisture climatology estimation, Remote Sens. Environ., 242, 111756, https://doi.org/10.1016/j.rse.2020.111756, 2020.

Dorigo, W. and de Jeu, R.: Satellite soil moisture for advancing our understanding of earth system processes and climate change, Int. J. Appl. Earth Obs., 48, 1-4, https://doi.org/10.1016/j.jag.2016.02.007, 2016.

Dorigo, W., Wagner, W., Albergel, C., Albrecht, F., Balsamo, G., Brocca, L., Chung, D., Ert, M., Forkel, M., Gruber, A., Haas, E., D., Hamer, P., Hirschi, M., Ikonen, J., de Jeu, R., Kidd, R., Lahoz, W., Liu, Y. Y., Miralles, D., Mistelbauer, T., Nicolai-Shaw, N., Parinussa, R., Pratola, C., Reimerak, C., van der Schalie, R., Seneviratne, S. I., Smolander, T., and Lecomte, P.: ESA CCI Soil Moisture for improved Earth system understanding: State-of-the art and future directions, Remote Sens. Environ., 203, 185-215, https://doi.org/10.1016/j.rse.2017.07.001, 2017.

Dorigo, W. A., Scipal, K., Parinussa, R. M., Liu, Y. Y., Wagner, W., de Jeu, R. A. M., and Naeimi, V.: Error characterisation of global active and passive microwave soil moisture datasets, Hydrol. Earth Syst. Sci., 14, 2605-2616, https://doi.org/10.5194/hess-142605-2010, 2010.

Dorigo, W. A., Wagner, W., Hohensinn, R., Hahn, S., Paulik, C., Xaver, A., Gruber, A., Drusch, M., Mecklenburg, S., van Oevelen, P., Robock, A., and Jackson, T.: The International Soil Moisture Network: a data hosting facility for global in situ soil moisture measurements, Hydrol. Earth Syst. Sci., 15, 1675-1698, https://doi.org/10.5194/hess-15-1675-2011, 2011.

Dorigo, W. A., Xaver, A., Vreugdenhil, M., Gruber, A., Hegyiová, A., Sanchis-Dufau, A. D., Zamojski, D., Cordes, C., Wagner, W., and Drusch, M.: Global automated quality control of in situ soil moisture data from the International Soil Moisture Network, Vadose Zone J., 12, https://doi.org/10.2136/vzj2012.0097, 2013.

Driessen, T. L. A., Hurkmans, R. T. W. L., Terink, W., Hazenberg, P., Torfs, P. J. J. F., and Uijlenhoet, R.: The hydrological response of the Ourthe catchment to climate change as mod- 
elled by the HBV model, Hydrol. Earth Syst. Sci., 14, 651-665, https://doi.org/10.5194/hess-14-651-2010, 2010.

Du, J., Kimball, J. S., Galantowicz, J., Kim, S.-B., Chan, S. K., Reichle, R., Jones, L. A., and Watts, J. D.: Assessing global surface water inundation dynamics using combined satellite information from SMAP, AMSR2 and Landsat, Remote Sens. Environ., 213, 1-17, https://doi.org/10.1016/j.rse.2018.04.054, 2018.

Ebert, E. E., Janowiak, J. E., and Kidd, C.: Comparison of nearreal-time precipitation estimates from satellite observations and numerical models, B. Am. Meteorol. Soc., 88, 47-64, 2007.

Entekhabi, D., Njoku, E. G., O’Neill, P. E., Kellogg, K. H., Crow, W. T., Edelstein, W. N., Entin, J. K., Goodman, S. D., Jackson, T. J., Johnson, J., Kimball, J., Piepmeier, J. R., Koster, R. D., Martin, N., McDonald, K. C., Moghaddam, M., Moran, S., Reichle, R., Shi, J. C., Spencer, M. W., Thurman, S. W., Tsang, L., and Van Zyl, J.: The Soil Moisture Active Passive (SMAP) mission, P. IEEE, 98, 704-716, 2010a.

Entekhabi, D., Reichle, R. H., Koster, R., and Crow, W. T.: Performance metrics for soil moisture retrievals and application requirements, J. Hydrometeorol., 11, 832-840, 2010 b.

Fang, L., Hain, C. R., Zhan, X., and Anderson, M. C.: An intercomparison of soil moisture data products from satellite remote sensing and a land surface model, Int. J. Appl. Earth Obs., 48, 37-50, https://doi.org/10.1016/j.jag.2015.10.006, 2016.

Fatichi, S., Vivoni, E. R., Ogden, F. L., Ivanov, V. Y., Mirus, B., Gochis, D., Downer, C. W., Camporese, M., Davison, J. H., Ebel, B., Jones, N., Kim, J., Mascaro, G., Niswonger, R., Restrepo, P., Rigon, R., Shen, C., Sulis, M., and Tarboton, D.: An overview of current applications, challenges, and future trends in distributed process-based models in hydrology, J. Hydrol., 537, 45-60, https://doi.org/10.1016/j.jhydrol.2016.03.026, 2016.

Fick, S. E. and Hijmans, R. J.: WorldClim 2: new 1km spatial resolution climate surfaces for global land areas, Int. J. Climatol., 37, 4302-4315, 2017.

Ford, T. W., Harris, E., and Quiring, S. M.: Estimating root zone soil moisture using near-surface observations from SMOS, Hydrol. Earth Syst. Sci., 18, 139-154, https://doi.org/10.5194/hess18-139-2014, 2014.

Gharari, S., Clark, M. P., Mizukami, N., Knoben, W. J. M., Wong, J. S., and Pietroniro, A.: Flexible vector-based spatial configurations in land models, Hydrol. Earth Syst. Sci. Discuss., https://doi.org/10.5194/hess-2020-111, in review, 2020.

Gottschalck, J., Meng, J., Rodell, M., and Houser, P.: Analysis of multiple precipitation products and preliminary assessment of their impact on Global Land Data Assimilation System land surface states, J. Hydrometeorol., 6, 573-598, 2005.

Griesfeller, A., Lahoz, W., Jeu, R., Dorigo, W., Haugen, L., Svendby, T., and Wagner, W.: Evaluation of satellite soil moisture products over Norway using ground-based observations, Int. J. Appl. Earth Obs., 45, 155-164, 2016.

Gruber, A., Su, C.-H., Zwieback, S., Crow, W., Dorigo, W., and Wagner, W.: Recent advances in (soil moisture) triple collocation analysis, Int. J. Appl. Earth Obs., 45, 200-211, 2016.

Gruber, A., Dorigo, W. A., Crow, W., and Wagner, W.: Triple collocation-based merging of satellite soil moisture retrievals, IEEE T. Geosci. Remote, 55, 6780-6792, 2017.

Gruber, A., Scanlon, T., van der Schalie, R., Wagner, W., and Dorigo, W.: Evolution of the ESA CCI Soil Moisture climate data records and their underlying merging methodology, Earth
Syst. Sci. Data, 11, 717-739, https://doi.org/10.5194/essd-11717-2019, 2019.

Gruber, A., De Lannoy, G., Al-Yaari, C. A. A., Brocca, L., Calvet, J.-C., Colliander, A., Cosh, M., Crow, W., Dorigo, W., Draper, C., Hirschi, M., Kerr, Y., Konings, A., Lahoz, W., McColl, K., Montzka, C., Muñoz-Sabater J., Peng, J., Reichle, R., Richaume, P., Rudiger, C., Scanlon, T., van der Schalie, R., Wigneron, J.-P., and Wagner, W.: Validation practices for satellite soil moisture retrievals: What are (the) errors?, Remote Sens. Environ., 244, 111806, https://doi.org/10.1016/j.rse.2020.111806, 2020.

Gruhier, C., de Rosnay, P., Kerr, Y., Mougin, E., Ceschia, E., Calvet, J.-C., and Richaume, P.: Evaluation of AMSR-E soil moisture product based on ground measurements over temperate and semi-arid regions, Geophys. Res. Lett., 35, L10405, https://doi.org/10.1029/2008GL033330, 2008.

Gruhier, C., de Rosnay, P., Hasenauer, S., Holmes, T., de Jeu, R., Kerr, Y., Mougin, E., Njoku, E., Timouk, F., Wagner, W., and Zribi, M.: Soil moisture active and passive microwave products: intercomparison and evaluation over a Sahelian site, Hydrol. Earth Syst. Sci., 14, 141-156, https://doi.org/10.5194/hess14-141-2010, 2010.

Guo, Y., Shi, J., Du, J., and Fu, X.: Evaluation of terrain effect on microwave radiometer measurement and its correction, Int. J. Remote Sens., 32, 8899-8913, 2011.

Guo, Z., Dirmeyer, P. A., Gao, X., and Zhao, M.: Improving the quality of simulated soil moisture with a multi-model ensemble approach, Q. J. Roy. Meteor. Soc., 133, 731-747, 2007.

Guswa, A. J., Celia, M. A., and Rodriguez-Iturbe, I.: Models of soil moisture dynamics in ecohydrology: a comparative study, Water Resour. Res., 38, 1166, https://doi.org/10.1029/2001WR000826, 2002.

Hargreaves, G. H.: Defining and using reference evapotranspiration, J. Irrig. Drain. E., 120, 1132-1139, 1994.

He, X., Pan, M., Wei, Z., Wood, E. F., and Sheffield, F.: A global drought and flood catalogue from 1950 to 2016, B. Am. Meteorol. Soc., 101, 508-535, 2020.

Hersbach, H., Bell, B., Berrisford, P., Hirahara, S., Horanyi, A., Muñoz-Sabater, J., Nicolas, J., Peubey, C., Radu, R., Schepers, D., Simmons, A., Soci, C., Abdalla, S., Abellan, X., Balsamo, G., Bechtold, P., Biavati, G., Bidlot, J., Bonavita, M., Chiara, G. D., Dahlgren, P., Dee, D., Diamantakis, M., Dragani, R., Flemming, J., Forbes, R., Fuentes, M., Geer, A., Haimberger, L., Healy, S., Hogan, R. J., Holm, E., Janiskova, M., Keeley, S., Laloyaux, P., Lopez, P., Radnoti, G., de Rosnay, P., Rozum, I., Vamborg, F., Villaume, S., and Thépaut, J.-N.: The ERA5 global reanalysis, Q. J. Roy. Meteorol. Soc., https://doi.org/10.1002/qj.3803, 2020.

Houser, P. R., Shuttleworth, W. J., Famiglietti, J. S., Gupta, H. V., Syed, K. H., and Goodrich, D. C.: Integration of soil moisture remote sensing and hydrologic modeling using data assimilation, Water Resour. Res., 34, 3405-3420, 1998.

H SAF: Metop ASCAT surface soil moisture climate data record v5 $12.5 \mathrm{~km}$ sampling (H115),EUMETSAT SAF on Support to Operational Hydrology and Water Management, https://doi.org/10.15770/EUM_SAF_H_0006, 2019a.

H SAF: ASCAT surface soil moisture climate data record v5 extension $12.5 \mathrm{~km}$ sampling - Metop (H116), EUMETSAT SAF on Support to Operational Hydrology and Water Management, available at: https://navigator.eumetsat.int/product/EO EUM:DAT:METOP:H116, last access: August 2019b. 
Huffman, G. J., Adler, R. F., Morrissey, M. M., Bolvin, D. T., Curtis, S., Joyce, R., McGavock, B., and Susskind, J.: Global precipitation at one-degree daily resolution from multi-satellite observations, J. Hydrometeorol., 2, 36-50, 2001.

Huffman, G. J., Bolvin, D. T., Braithwaite, D., Hsu, K., Joyce, R., Kidd, C., Nelkin, E. J., and Xie, P.: NASA Global Precipitation Measurement (GPM) Integrated Multi-satellitE Retrievals for GPM (IMERG), Algorithm Theoretical Basis Document (ATBD), NASA/GSFC, Greenbelt, MD, USA, 2014.

Huffman, G. J., Bolvin, D. T., and Nelkin, E. J.: Integrated MultisatellitE Retrievals for GPM (IMERG) Technical Documentation, Tech. rep., NASA/GSFC, Greenbelt, MD, USA, 2018.

Huffman, G. J., Stocker, E. F., Bolvin, D. T., Nelkin, E. J., and Tan, J.: GPM IMERG Late Precipitation L3 Half Hourly 0.1 degree x 0.1 degree V06, Greenbelt, MD, Goddard Earth Sciences Data and Information Services Center (GES DISC), https://doi.org/10.5067/GPM/IMERG/3B-HH-L/06, 2019.

Jackson, T. J., Cosh, M. H., Bindlish, R., Starks, P. J., Bosch, D. D., Seyfried, M., Goodrich, D. C., Moran, M. S., and Du, J.: Validation of Advanced Microwave Scanning Radiometer soil moisture products, IEEE T. Geosci. Remote, 48, 4256-4272, 2010.

Jin, R., Li, X., Yan, B., Li, X., Luo, W., Ma, M., Guo, J., Kang, J., Zhu, Z., and Zhao, S.: A nested ecohydrological wireless sensor network for capturing the surface heterogeneity in the midstream areas of the Heihe river basin, China, IEEE Geosci. Remote S., 11, 2015-2019, 2014.

Jódar, J., Carpintero, E., Martos-Rosillo, S., Ruiz-Constán, A., Marín-Lechado, C., Cabrera-Arrabal, J. A., NavarreteMazariegos, E., González-Ramón, A., Lambán, L. J., Herrera, C., and González-Dugo, M. P.: Combination of lumped hydrological and remote-sensing models to evaluate water resources in a semi-arid high altitude ungauged watershed of Sierra Nevada (Southern Spain), Sci. Total Environ., 625, 285-300, https://doi.org/10.1016/j.scitotenv.2017.12.300, 2018.

Kang, C. S., Kanniah, K. D., Kerr, Y. H., and Cracknell, A. P.: Analysis of in-situ soil moisture data and validation of SMOS soil moisture products at selected agricultural sites over a tropical region, Int. J. Remote, 37, 3636-3654, 2016.

Kang, J., Li, X., Jin, R., Ge, Y., Wang, J., and Wang, J.: Hybrid optimal design of the eco-hydrological wireless sensor network in the middle reach of the Heihe river basin, China, Sensors, 14, 19095-19114, https://doi.org/10.3390/s141019095, 2014.

Karthikeyan, L. and Kumar, D. N.: A novel approach to validate satellite soil moisture retrievals using precipitation data, J. Geophys. Res.-Atmos., 121, 11516-11535, 2016.

Karthikeyan, L., Pan, M., Wanders, N., Kumar, D. N., and Wood, E. F.: Four decades of microwave satellite soil moisture observations: Part 2. Product validation and intersatellite comparisons, Adv. Water Resour., 109, 236-252, https://doi.org/10.1016/j.advwatres.2017.09.010, 2017a.

Karthikeyan, L., Pan, M., Wanders, N., Kumar, D. N., and Wood, E. F.: Four decades of microwave satellite soil moisture observations: Part 1. A review of retrieval algorithms, Adv. Water Resour., 109, 106-120, https://doi.org/10.1016/j.advwatres.2017.09.006, 2017b.

Karthikeyan, L., Chawla, I., and Mishra, A. K.: A review of remote sensing applications in agriculture for food security: crop growth and yield, irrigation, and crop losses, J. Hydrol., 124905, https://doi.org/10.1016/j.jhydrol.2020.124905, 2020.
Kauffeldt, A., Wetterhall, F., Pappenberger, F., Salamon, P., and Thielen, J.: Technical review of large-scale hydrological models for implementation in operational flood forecasting schemes on continental level, Environ. Modell. Softw., 75, 68-76, https://doi.org/10.1016/j.envsoft.2015.09.009, 2016.

Kerr, Y. H., Waldteufel, P., Richaume, P., Wigneron, J. P., Ferrazzoli, P., Mahmoodi, A., Al Bitar, A., Cabot, F., Gruhier, C., Juglea, S. E., Leroux, D., Mialon, A., and Delwart, S.: The SMOS soil moisture retrieval algorithm, IEEE T. Geosci. Remote, 50, 1384-1403, 2012

Kidd, C., Becker, A., Huffman, G. J., Muller, C. L., Joe, P., Skofronick-Jackson, G., and Kirschbaum, D. B.: So, how much of the Earth's surface is covered by rain gauges?, B. Am. Meteorol. Soc., 98, 69-78, 2017.

Kim, H., Parinussa, R., Konings, A. G., Wagner, W., Cosh, M. H., Lakshmi, V., Zohaib, M., and Choi, M.: Global-scale assessment and combination of SMAP with ASCAT (active) and AMSR2 (passive) soil moisture products, Remote Sens. Environ., 204, 260-275, https://doi.org/10.1016/j.rse.2017.10.026, 2018.

Kirchner, J. W.: Getting the right answers for the right reasons: Linking measurements, analyses, and models to advance the science of hydrology, Water Resour. Res., 42, W03S04, https://doi.org/10.1029/2005WR004362, 2006.

Knutti, R.: Should we believe model predictions of future climate change?, Philos. T. R. Soc. S-A., 366, 4647-4664, 2008.

Koren, V., Moreda, F., and Smith, M.: Use of soil moisture observations to improve parameter consistency in watershed calibration, Phys. Chem. Earth, 33, 1068-1080, 2008.

Koster, R. D., Guo, Z., Yang, R., Dirmeyer, P. A., Mitchell, K., and Puma, M. J.: On the nature of soil moisture in land surface models, J. Climate, 22, 4322-4335, 2009.

Koster, R. D., Liu, Q., Mahanama, S. P. P., and Reichle, R. H.: Improved hydrological simulation using SMAP data: relative impacts of model calibration and data assimilation, J. Hydrometeorol., 19, 727-741, 2018.

Kruskal, W. H. and Wallis, W. A.: Use of Ranks in One-Criterion Variance Analysis, J. Am. Stat. Assoc., 47, 583-621, 1952.

Kumar, S. V., Peters-Lidard, C. D., Mocko, D., Reichle, R., Liu, Y., Arsenault, K. R., Xia, Y., Ek, M., Riggs, G., Livneh, B., and Cosh, M.: Assimilation of remotely sensed soil moisture and snow depth retrievals for drought estimation, J. Hydrometeorol., 15, 2446-2469, 2014.

Lahoz, W. A. and De Lannoy, G. J. M.: Closing the gaps in our knowledge of the hydrological cycle over land: conceptual problems, Surv. Geophys., 35, 623-660, 2014.

Laiolo, P., Gabellani, S., Campo, L., Silvestro, F., Delogu, F., Rudari, R., Pulvirenti, L., Boni, G., Fascetti, F., Pierdicca, N., Crapolicchio, R., Hasenauer, S., and Puca, S.: Impact of different satellite soil moisture products on the predictions of a continuous distributed hydrological model, Int. J. Appl. Earth Obs., 48, 131-145, https://doi.org/10.1016/j.jag.2015.06.002, 2016.

Lei, F., Crow, W. T., Shen, H., Parinussa, R. M., and Holmes, T. R. H.: The impact of local acquisition time on the accuracy of microwave surface soil moisture retrievals over the contiguous United States, Remote Sens.-Basel, 7, 13448-13465, 2015.

Liu, J.-G. and Xie, Z.-H.: Improving simulation of soil moisture in China using a multiple meteorological forcing ensemble approach, Hydrol. Earth Syst. Sci., 17, 3355-3369, https://doi.org/10.5194/hess-17-3355-2013, 2013. 
Liu, Q., Reichle, R. H., Bindlish, R., Cosh, M. H., Crow, W. T., de Jeu, R. A. M., De Lannoy, G. J. M., Huffman, G. J., and Jackson, T. J.: The contributions of precipitation and soil moisture observations to the skill of soil moisture estimates in a land data assimilation system, J. Hydrometeorol., 12, 750-765, 2011.

Liu, Y., Weerts, A. H., Clark, M., Hendricks Franssen, H.-J., Kumar, S., Moradkhani, H., Seo, D.-J., Schwanenberg, D., Smith, P., van Dijk, A. I. J. M., van Velzen, N., He, M., Lee, H., Noh, S. J., Rakovec, O., and Restrepo, P.: Advancing data assimilation in operational hydrologic forecasting: progresses, challenges, and emerging opportunities, Hydrol. Earth Syst. Sci., 16, 3863-3887, https://doi.org/10.5194/hess-16-3863-2012, 2012.

Liu, Y., Liu, Y., and Wang, W.: Inter-comparison of satelliteretrieved and Global Land Data Assimilation System-simulated soil moisture datasets for global drought analysis, Remote Sens. Environ., 220, 1-18, https://doi.org/10.1016/j.rse.2018.10.026, 2019.

Loew, A., Dall'Amico, J. T., Schlenz, F., and Mauser, W.: The Upper Danube soil moisture validation site: measurements and activities, in: Proceedings of the Symposium Earth Observation and Water Cycle Science, 20-23 October 2015, Frascati, Italy, 2009.

Long, D. and Ulaby, F. T.: Microwave radar and radiometric remote sensing, Artech House, 2015.

López López, P., Wanders, N., Schellekens, J., Renzullo, L. J., Sutanudjaja, E. H., and Bierkens, M. F. P.: Improved large-scale hydrological modelling through the assimilation of streamflow and downscaled satellite soil moisture observations, Hydrol. Earth Syst. Sci., 20, 3059-3076, https://doi.org/10.5194/hess-20-30592016, 2016.

Lü, H., Crow, W. T., Zhu, Y., Ouyang, F., and Su, J.: Improving streamflow prediction using remotely-sensed soil moisture and snow depth, Remote Sens.-Basel, 8, 503, https://doi.org/10.3390/rs8060503, 2016.

Lv, S., Zeng, Y., Wen, J., Zhao, H., and Su, Z.: Estimation of penetration depth from soil effective temperature in microwave radiometry, Remote Sens.-Basel, 10, 519, https://doi.org/10.3390/rs10040519, 2018.

Ma, H., Zeng, J., Chen, N., Zhang, X., Cosh, M. H., and Wang, W.: Satellite surface soil moisture from SMAP, SMOS, AMSR2 and ESA CCI: A comprehensive assessment using global ground-based observations, Remote Sens. Environ., 231, 111215, https://doi.org/10.1016/j.rse.2019.111215, 2019.

Marczewski, W., Slominski, J., Slominska, E., Usowicz, B., Usowicz, J., Romanov, S., Maryskevych, O., Nastula, J., and Zawadzki, J.: Strategies for validating and directions for employing SMOS data, in the Cal-Val project SWEX (3275) for wetlands, Hydrol. Earth Syst. Sci. Discuss., 7, 7007-7057, https://doi.org/10.5194/hessd-7-7007-2010, 2010.

Martens, B., Miralles, D., Lievens, H., Fernández-Prieto, D., and Verhoest, N.: Improving terrestrial evaporation estimates over continental Australia through assimilation of SMOS soil moisture, Int. J. Appl. Earth Obs., 48, 146-162, https://doi.org/10.1016/j.jag.2015.09.012, 2016.

Martens, B., Miralles, D. G., Lievens, H., van der Schalie, R., de Jeu, R. A. M., Fernández-Prieto, D., Beck, H. E., Dorigo, W. A., and Verhoest, N. E. C.: GLEAM v3: satellite-based land evaporation and root-zone soil moisture, Geosci. Model Dev., 10, 19031925, https://doi.org/10.5194/gmd-10-1903-2017, 2017.
Massari, C., Crow, W., and Brocca, L.: An assessment of the performance of global rainfall estimates without groundbased observations, Hydrol. Earth Syst. Sci., 21, 4347-4361, https://doi.org/10.5194/hess-21-4347-2017, 2017.

Mattar, C., Santamaría-Artigas, A., Durán-Alarcón, C., OliveraGuerra, L., and Fuster, R.: LAB-net the First Chilean soil moisture network for remote sensing applications, in: Quantitative Remote Sensing Symposium (RAQRS), 22-26 September 2014, Valencia, Spain, 2014.

McCabe, M. F., Ershadi, A., Jimenez, C., Miralles, D. G., Michel, D., and Wood, E. F.: The GEWEX LandFlux project: evaluation of model evaporation using tower-based and globally gridded forcing data, Geosci. Model Dev., 9, 283-305, https://doi.org/10.5194/gmd-9-283-2016, 2016.

McColl, K. A., Kaighin, A., Vogelzang, J., Konings, A. G., Entekhabi, D., Piles, M., and Stoffelen, A.: Extended triple collocation: Estimating errors and correlation coefficients with respect to an unknown target, Geophys. Res. Lett., 41, 6229-6236, 2014.

McKay, M. D., Conover, W. J., and Beckman, R. J.: A comparison of three methods for selecting values of input variables in the analysis of output from a computer code, Technometrics, 21, 239-245, 1979.

Mendoza, P. A., Clark, M. P., Barlage, M., Rajagopalan, B., Samaniego, L., Abramowitz, G., and Gupta, H.: Are we unnecessarily constraining the agility of complex process-based models?, Water Resour. Res., 51, 716-728, https://doi.org/10.1002/2014WR015820, 2015.

Mialon, A., Coret, L., Kerr, Y. H., Secherre, F., and Wigneron, J.: Flagging the topographic impact on the SMOS signal, IEEE T. Geosci. Remote, 46, 689-694, 2008.

Miralles, D. G., Crow, W. T., and Cosh, M. H.: Estimating spatial sampling errors in coarse-scale soil moisture estimates derived from point-scale observations, J. Hydrometeorol., 11, 14231429, 2010.

Miralles, D. G., Gentine, P., Seneviratne, S. I., and Teuling, A. J.: Land-atmospheric feedbacks during droughts and heatwaves: state of the science and current challenges, Ann. N.Y. Acad. Sci., 1436, 19-35, https://doi.org/10.1111/nyas.13912, 2019.

Miyaoka, K., Gruber, A., Ticconi, F., Hahn, S., Wagner, W., Saldana, J. F., and Anderson, C.: Triple collocation analysis of soil moisture from Metop-A ASCAT and SMOS against JRA-55 and ERA-Interim, IEEE J. Sel. Top. App., 10, 2274-2284, 2017.

Moghaddam, M., Entekhabi, D., Goykhman, Y., Li, K., Liu, M., Mahajan, A., Nayyar, A., Shuman, D., and Teneketzis, D.: A wireless soil moisture smart sensor web using physics-based optimal control: concept and initial demonstrations, IEEE J. Sel. Top. Appl., 3, 522-535, 2010.

Moghaddam, M., Silva, A., Clewley, D., Akbar, R., Hussaini, S., Whitcomb, J., Devarakonda, R., Shrestha, R., Cook, R., Prakash, G., Santhana Vannan, S., and Boyer, A.: Soil Moisture Profiles and Temperature Data from SoilSCAPE Sites, USA, availabe lat: http://daac.ornl.gov/cgi-bin/dsviewer.pl?ds_ id=1339 (last access: August 2019), 2016.

Montero, R. A., Schwanenberg, D., Krahe, P., Lisniak, D., Sensoy, A., Sorman, A. A., and Akkol, B.: Moving horizon estimation for assimilating $\mathrm{H}-\mathrm{SAF}$ remote sensing data into the HBV hydrological model, Adv. Water Resour., 92, 248-257, 2016.

Moradkhani, H.: Hydrologic remote sensing and land surface data assimilation, Sensors, 8, 2986-3004, 2008. 
Morbidelli, R., Saltalippi, C., Flammini, A., Rossi, E., and Corradini, C.: Soil water content vertical profiles under natural conditions: matching of experiments and simulations by a conceptual model, Hydrol. Process., 28, 4732-4742, 2014.

Muñoz Sabater, J., Lawrence, H., Albergel, C., Rosnay, P., Isaksen, L., Mecklenburg, S., Kerr, Y., and Drusch, M.: Assimilation of SMOS brightness temperatures in the ECMWF Integrated Forecasting System, Q. J. Roy. Meteorol. Soc., 145, 2524-2548, 2019.

Myeni, L., Moeletsi, M. E., and Clulow, A. D.: Present status of soil moisture estimation over the African continent, J. Hydrol., 21, 14-24, https://doi.org/10.1016/j.ejrh.2018.11.004, 2019.

Naz, B. S., Kurtz, W., Montzka, C., Sharples, W., Goergen, K., Keune, J., Gao, H., Springer, A., Hendricks Franssen, H.-J., and Kollet, S.: Improving soil moisture and runoff simulations at 3 $\mathrm{km}$ over Europe using land surface data assimilation, Hydrol. Earth Syst. Sci., 23, 277-301, https://doi.org/10.5194/hess-23277-2019, 2019.

Njoku, E. G., Ashcroft, P., Chan, T. K., and Li, L.: Global survey and statistics of radio-frequency interference in AMSR-E land observations, IEEE T. Geosci. Remote, 43, 938-947, 2005.

Ochsner, T. E., Cosh, M. H., Cuenca, R. H., Dorigo, W. A., Draper, C. S., Hagimoto, Y., Kerr, Y. H., Larson, K. M., Njoku, E. G., Small, E. E., and Zreda, M.: State of the art in large-scale soil moisture monitoring, Soil Sci. Soc. Am. J., 77, 1888-1919, 2013.

Ojo, E. R., Bullock, P. R., L'Heureux, J., Powers, J., McNairn, H., and Pacheco, A.: Calibration and evaluation of a frequency domain reflectometry sensor for realtime soil moisture monitoring, Vadose Zone J., 14, 1-12, https://doi.org/10.2136/vzj2014.08.0114, 2015.

Oliva, R., Daganzo, E., Kerr, Y. H., Mecklenburg, S., Nieto, S., Richaume, P., and Gruhier, C.: SMOS radio frequency interference scenario: status and actions taken to improve the RFI environment in the 1400-1427-MHz passive band, IEEE T. Geosci. Remote, 50, 1427-1439, 2012.

O’Neill, P. E., Chan, S., Njoku, E. G., Jackson, T., and Bindlish, R.: SMAP Enhanced L3 radiometer global daily 9km EASEgrid soil moisture, version 3, National Snow and Ice Data Center, Boulder, USA, https://doi.org/10.5067/T90W6VRLCBHI, 2019.

Orth, R., Staudinger, M., Seneviratne, S. I., Seibert, J., and Zappa, M.: Does model performance improve with complexity? A case study with three hydrological models, J. Hydrol., 523, 147-159, https://doi.org/10.1016/j.jhydrol.2015.01.044, 2015.

Osenga, E. C., Arnott, J. C., Endsley, K. A., and Katzenberger, J. W.: Bioclimatic and soil moisture monitoring across elevation in a mountain watershed: opportunities for research and resource management, Water Resour. Res., 55, 2493-2503, 2019.

Pablos, M., González-Zamora, A., Sánchez, N., and MartínezFernández, J.: Assessment of root zone soil moisture estimations from SMAP, SMOS and MODIS observations, Remote Sens.Basel, 10, 981, https://doi.org/10.3390/rs10070981, 2018.

Pan, M. and Wood, E. F.: Impact of accuracy, spatial availability, and revisit time of satellite-derived surface soil moisture in a multiscale ensemble data assimilation system, IEEE J. Sel. Top. Appl., 3, 49-56, 2010.

Pan, M., Wood, E. F., McLaughlin, D. B., Entekhabi, D., and Luo, L.: A multiscale ensemble filtering system for hydrologic data assimilation. Part I: Implementation and synthetic experiment, J. Hydrometeorol., 10, 794-806, 2009.
Parajka, J., Naeimi, V., Blöschl, G., Wagner, W., Merz, R., and Scipal, K.: Assimilating scatterometer soil moisture data into conceptual hydrologic models at the regional scale, Hydrol. Earth Syst. Sci., 10, 353-368, https://doi.org/10.5194/hess-10353-2006, 2006.

Parinussa, R. M., Holmes, T. R. H., Yilmaz, M. T., and Crow, W. T.: The impact of land surface temperature on soil moisture anomaly detection from passive microwave observations, Hydrol. Earth Syst. Sci., 15, 3135-3151, https://doi.org/10.5194/hess-15-31352011, 2011.

Parinussa, R. M., Holmes, T. R. H., Wanders, N., Dorigo, W. A., and de Jeu, R. A. M.: A preliminary study toward consistent soil moisture from AMSR2, J. Hydrometeorol., 16, 932-947, 2015.

Paulik, C., Dorigo, W., Wagner, W., and Kidd, R.: Validation of the ASCAT Soil Water Index using in situ data from the International Soil Moisture Network, Int. J. Appl. Earth Obs., 30, 1-8, https://doi.org/10.1016/j.jag.2014.01.007, 2014.

Pellarin, T., Calvet, J.-C., and Wagner, W.: Evaluation of ERS scatterometer soil moisture products over a half-degree region in southwestern France, Geophys. Res. Lett., 33, L17401, https://doi.org/10.1029/2006GL027231, 2006.

Petropoulos, G. P. and McCalmont, J. P.: An operational in situ soil moisture \& soil temperature monitoring network for West Wales, UK: the WSMN network, Sensors, 17, 7, https://doi.org/10.3390/s17071481, 2017.

Petropoulos, G. P., Ireland, G., and Barrett, B.: Surface soil moisture retrievals from remote sensing: Current status, products \& future trends, Phys. Chem. Earth, 83/84, 36-56, https://doi.org/10.1016/j.pce.2015.02.009, 2015.

Piepmeier, J. R., Johnson, J. T., Mohammed, P. N., Bradley, D., Ruf, C., Aksoy, M., Garcia, R., Hudson, D., Miles, L., and Wong, M.: Radio-frequency interference mitigation for the Soil Moisture Active Passive microwave radiometer, IEEE T. Geosci. Remote, 52, 761-775, 2014.

Pulvirenti, L., Pierdicca, N., and Marzano, F. S.: Prediction of the error induced by topography in satellite microwave radiometric observations, IEEE T. Geosci. Remote, 49, 3180-3188, 2011.

Reichle, R. H. and Koster, R. D.: Bias reduction in short records of satellite soil moisture, Geophys. Res. Lett., 31, L19501, https://doi.org/10.1029/2004GL020938, 2004.

Reichle, R. H., De Lannoy, G. J. M., Liu, Q., Ardizzone, J. V., Colliander, A., Conaty, A., Crow, W., Jackson, T. J., Jones, L. A., Kimball, J. S., Koster, R. D., Mahanama, S. P., Smith, E. B., Berg, A., Bircher, S., Bosch, D., Caldwell, T. G., Cosh, M., González-Zamora, L., Collins, C. D. H., Jensen, K. H., Livingston, S., Lopez-Baeza, E., Martínez-Fernández, J., McNairn, H., Moghaddam, M., Pacheco, A., Pellarin, T., Prueger, J., Rowlandson, T., Seyfried, M., Starks, P., Su, Z., Thibeault, M., van der Velde, R., Walker, J., Wu, X., Zeng, Y., Reichle, R. H., De Lannoy, G. J. M., Liu, Q., Ardizzone, J. V., Colliander, A., Conaty, A., Crow, W., Jackson, T. J., Jones, L. A., Kimball, J. S., Koster, R. D., Mahanama, S. P., Smith, E. B., Berg, A., Bircher, S., Bosch, D., Caldwell, T. G., Cosh, M., González-Zamora, A., Collins, C. D. H., Jensen, K. H., Livingston, S., Lopez-Baeza, E., Martínez-Fernández, J., McNairn, H., Moghaddam, M., Pacheco, A., Pellarin, T., Prueger, J., Rowlandson, T., Seyfried, M., Starks, P., Su, Z., Thibeault, M., van der Velde, R., Walker, J., Wu, X., and Zeng, Y.: Assessment of the SMAP Level-4 surface and root- 
zone soil moisture product using in situ measurements, J. Hydrometeorol., 18, 2621-2645, 2017.

Reichle, R., De Lannoy, G., Koster, R. D., Crow, W. T., Kimball, J. S., and Liu, Q.: SMAP L4 global 3-hourly 9km EASEgrid surface and root zone soil moisture geophysical data, version 4, National Snow and Ice Data Center, Boulder, USA, https://doi.org/10.5067/KPJNN2GI1DQR, 2019a.

Reichle, R. H., Liu, Q., Koster, R. D., Crow, W. T., De Lannoy, G. J. M., Kimball, J. S., Ardizzone, J. V., Bosch, D., Colliander, A., Cosh, M., Kolassa, J., Mahanama, S. P., Prueger, J., Starks, P., and Walker, J. P.: Version 4 of the SMAP level-4 soil moisture algorithm and data product, J. Adv. Model. Earth Sy., 11, 31063130, 2019b.

Rodell, M., Houser, P., Jambor, U., Gottschalck, J., Mitchell, K., Meng, C.-J., Arsenault, K., Cosgrove, B., Radakovich, J., Bosilovich, M., Entin, J., Walker, J., Lohmann, D., and Toll, D.: The Global Land Data Assimilation System, B. Am. Meteorol. Soc., 85, 381-394, 2004.

Rondinelli, W. J., Hornbuckle, B. K., Patton, J. C., Cosh, M. H., Walker, V. A., Carr, B. D., and Logsdon, S. D.: Different rates of soil drying after rainfall are observed by the SMOS satellite and the South Fork in situ soil moisture network, J. Hydrometeorol., 16, 889-903, 2015.

Rui, H., Beaudoing, H., and Loeser, C.: README document for NASA GLDAS version 2 data products, NASA Goddard Earth Science Data Information and Services Center (GES DISC), Greenbelt, Maryland, USA, availabe at: https://hydro1.gesdisc. eosdis.nasa.gov/data/GLDAS/README_GLDAS2.pdf (last access: August 2019), 2020

Samaniego, L., Kumar, R., and Attinger, S.: Multiscale parameter regionalization of a grid-based hydrologic model at the mesoscale, Water Resour. Res., 46, W05523, https://doi.org/10.1029/2008WR007327, 2010.

Scipal, K., Holmes, T., de Jeu, R., Naeimi, V., and Wagner, W.: A possible solution for the problem of estimating the error structure of global soil moisture data sets, Geophys. Res. Lett., 35, L24403, https://doi.org/10.1029/2008GL035599, 2008.

Sheffield, J., Goteti, G., and Wood, E. F.: Development of a 50-year high-resolution global dataset of meteorological forcings for land surface modeling, J. Climate, 19, 3088-3111, 2006.

Shellito, P. J., Small, E. E., Colliander, A., Bindlish, R., Cosh, M. H., Berg, A. A., Bosch, D. D., Caldwell, T. G., Goodrich, D. C., McNairn, H., Prueger, J. H., Starks, P. J., van der Velde, R., and Walker, J. P.: SMAP soil moisture drying more rapid than observed in situ following rainfall events, Geophys. Res. Lett., 43, 8068-8075, 2016a.

Shellito, P. J., Small, E. E., and Cosh, M. H.: Calibration of Noah soil hydraulic property parameters using surface soil moisture from SMOS and basinwide in situ observations, J. Hydrometeorol., 17, 2275-2292, 2016b.

Singh, G., Das, N. N., Panda, R. K., Colliander, A., Jackson, T. J., Mohanty, B. P., Entekhabi, D., and Yueh, S. H.: Validation of SMAP soil moisture products using ground-based observations for the paddy dominated tropical region of India, IEEE T. Geosci. Remote, 57, 8479-8491, 2019.

Smith, A. B., Walker, J. P., Western, A. W., Young, R. I., Ellett, K. M., Pipunic, R. C., Grayson, R. B., Siriwardena, L., Chiew, F. H. S., and Richter, H.: The Murrumbidgee soil moisture monitoring network data set, Water Resour. Res., 48, W07701, https://doi.org/10.1029/2012WR011976, 2012.

Steele-Dunne, S., Lynch, P., McGrath, R., Semmler, T., Wang, S., Hanafin, J., and Nolan, P.: The impacts of climate change on hydrology in Ireland, J. Hydrol., 356, 28-45, 2008.

Su, C.-H., Narsey, S. Y., Gruber, A., Xaver, A., Chung, D., Ryu, D., and Wagner, W.: Evaluation of post-retrieval de-noising of active and passive microwave satellite soil moisture, Remote Sens. Environ., 163, 127-139, https://doi.org/10.1016/j.rse.2015.03.010, 2015.

Su, C.-H., Zhang, J., Gruber, A., Parinussa, R., Ryu, D., Crow, W. T., and Wagner, W.: Error decomposition of nine passive and active microwave satellite soil moisture data sets over Australia, Remote Sens. Environ., 182, 128-140, https://doi.org/10.1016/j.rse.2016.05.008, 2016.

Tagesson, T., Fensholt, R., Guiro, I., Rasmussen, M. O., Huber, S., Mbow, C., Garcia, M., Horion, S., Sandholt, I., HolmRasmussen, B., Göttsche, F. M., Ridler, M.-E., Olén, N., Lundegard Olsen, J., Ehammer, A., Madsen, M., Olesen, F. S., and Ardö, J.: Ecosystem properties of semiarid savanna grassland in West Africa and its relationship with environmental variability, Glob. Change Biol., 21, 250-264, 2015.

Tavakol, A., Rahmani, V., Quiring, S. M., and Kumar, S. V.: Evaluation analysis of NASA SMAP L3 and L4 and SPoRT-LIS soil moisture data in the United States, Remote Sens. Environ., 229, 234-246, https://doi.org/10.1016/j.rse.2019.05.006, 2019.

Teuling, A. J., Uijlenhoet, R., van den Hurk, B., and Seneviratne, S. I.: Parameter sensitivity in LSMs: An analysis using stochastic soil moisture models and ELDAS soil parameters, J. Hydrometeorol., 10, 751-765, 2009.

Thorstensen, A., Nguyen, P., Hsu, K., and Sorooshian, S.: Using densely distributed soil moisture observations for calibration of a hydrologic model, J. Hydrometeorol., 17, 571-590, 2016.

Tian, S., Renzullo, L. J., van Dijk, A. I. J. M., Tregoning, P., and Walker, J. P.: Global joint assimilation of GRACE and SMOS for improved estimation of root-zone soil moisture and vegetation response, Hydrol. Earth Syst. Sci., 23, 1067-1081, https://doi.org/10.5194/hess-23-1067-2019, 2019.

Ticconi, F., Anderson, C., Figa-Saldana, J., Wilson, J. J. W., and Bauch, H.: Analysis of radio frequency interference in Metop ASCAT backscatter measurements, IEEE J. Sel. Top. Appl., 10, 2360-2371, 2017.

Tobin, K. J., Crow, W. T., Dong, J., and Bennett, M. E.: Validation of a new root-zone soil moisture product: Soil MERGE, IEEE J. Sel. Top. Appl., 12, 3351-3365, 2019.

Van Cleve, K., Chapin, F. S., Stuart, R., and Roger, W.: Bonanza Creek long term ecological research project climate database, availabe at: http://www.lter.uaf.edu (last access: August 2019), 2015.

Vereecken, H., Huisman, J. A., Bogena, H., Vanderborght, J., Vrugt, J. A., and Hopmans, J. W.: On the value of soil moisture measurements in vadose zone hydrology: A review, Water Resour. Res. 44, W00D06, https://doi.org/10.1029/2008WR006829, 2008.

Vergopolan, N., Chaney, N. W., Beck, H. E., Pan, M., Sheffield, J., Chan, S., and Wood, E. F.: Combining hyper-resolution land surface modeling with SMAP brightness temperatures to obtain 30m soil moisture estimates, Remote Sens. Environ., 242, 111740, https://doi.org/10.1016/j.rse.2020.111740, 2020. 
Vetter, T., Huang, S., Aich, V., Yang, T., Wang, X., Krysanova, V., and Hattermann, F.: Multi-model climate impact assessment and intercomparison for three large-scale river basins on three continents, Earth Syst. Dynam., 6, 17-43, https://doi.org/10.5194/esd6-17-2015, 2015.

Wagner, W., Lemoine, G., and Rott, H.: A method for estimating soil moisture from ERS scatterometer and soil data, Remote Sens. Environ., 70, 191-207, 1999.

Wagner, W., Blöschl, G., Pampaloni, P., Calvet, J.-C., Bizzarri, B., Wigneron, J.-P., and Kerr, Y.: Operational readiness of microwave remote sensing of soil moisture for hydrologic applications, Hydrol. Res., 38, 1-20, 2007.

Wagner, W., Hahn, S., Kidd, R., Melzer, T., Bartalis, Z., Hasenauer, S., Saldana, J. F., de Rosnay, P., Jann, A., Schneider, S., Komma, J., Kubu, G., Gerhard, B., Katharina, A., Aubrecht, C., Züger, J., Gangkofner, U., Kienberger, S., Brocca, L., Wang, Y., Blöschl, G., Eitzinger, J., Steinnocher, K., Zeil, P., and Rubel, F.: The ASCAT soil moisture product: a review of its specifications, validation results, and emerging applications, Meteorol. Z., 22, 5-33, 2013.

Wanders, N., Bierkens, M. F. P., de Jong, S. M., de Roo, A., and Karssenberg, D.: The benefits of using remotely sensed soil moisture in parameter identification of large-scale hydrological models, Water Resour. Res., 50, 6874-6891, 2014.

Wang, H. and Yong, B.: Quasi-global evaluation of IMERG and GSMaP precipitation products over land using gauge observations, Water, 12, 243, https://doi.org/10.3390/w12010243, 2020.

Wu, Q., Liu, H., Wang, L., and Deng, C.: Evaluation of AMSR2 soil moisture products over the contiguous United States using in situ data from the International Soil Moisture Network, Int. J. Appl. Earth Obs., 45, 187-199, 2016.

Xia, Y., Hao, Z., Shi, C., Li, Y., Meng, J., Xu, T., Wu, X., and Zhang, B.: Regional and global land data assimilation systems: Innovations, challenges, and prospects, J. Meteorol. Res.-Prc., 33, 159$189,2019$.

Yamazaki, D., Ikeshima, D., Tawatari, R., Yamaguchi, T., O’Loughlin, F., Neal, J. C., Sampson, C. C., Kanae, S., and Bates, P. D.: A high-accuracy map of global terrain elevations, Geophys. Res. Lett., 44, 5844-5853, 2017.

Yang, K., Qin, J., Zhao, L., Chen, Y., Tang, W., Han, M., Lazhu, Chen, Z., Lv, N., Ding, B., Wu, H., and Lin, C.: A multiscale soil moisture and freeze-thaw monitoring network on the third pole, B. Ame. Meteorol. Soc., 94, 1907-1916, 2013.

Ye, N., Walker, J., Guerschman, J., Ryu, D., and Gurney, R.: Standing water effect on soil moisture retrieval from L-band passive microwave observations, Remote Sens. Environ., 169, 232-242, https://doi.org/10.1016/j.rse.2015.08.013, 2015.
Yilmaz, M. T. and Crow, W. T.: Evaluation of assumptions in soil moisture triple collocation analysis, J. Hydrometeorol., 15, 1293-1302, 2014.

Yilmaz, M. T., Crow, W. T., Anderson, M. C., and Hain, C.: An objective methodology for merging satellite- and modelbased soil moisture products, Water Resour. Res., 48, W11502, https://doi.org/10.1029/2011WR011682, 2012.

Zacharias, S., Bogena, H., Samaniego, L., Mauder, M., Fuß, R., Pütz, T., Frenzel, M., Schwank, M., Baessler, C., ButterbachBahl, K., Bens, O., Borg, E., Brauer, A., Dietrich, P., Hajnsek, I., Helle, G., Kiese, R., Kunstmann, H., Klotz, S., Munch, J. C., Papen, H., Priesack, E., Schmid, H. P., Steinbrecher, R., Rosenbaum, U., Teutsch, G., and Vereecken, H.: A network of terrestrial environmental observatories in Germany, Vadose Zone J., 10, 955-973, 2011.

Zhang, D. and Zhou, G.: Estimation of soil moisture from optical and thermal remote sensing: A review, Sensors, 16, 1308, https://doi.org/10.3390/s16081308, 2016.

Zhang, R., Kim, S., and Sharma, A.: A comprehensive validation of the SMAP Enhanced Level-3 Soil Moisture product using ground measurements over varied climates and landscapes, Remote Sens. Environ., 223, 82-94, https://doi.org/10.1016/j.rse.2019.01.015, 2019.

Zhang, X., Zhang, T., Zhou, P., Shao, Y., and Gao, S.: Validation analysis of SMAP and AMSR2 soil moisture products over the United States using ground-based measurements, Remote Sens.Basel, 9, 104, https://doi.org/10.3390/rs9020104, 2017.

Zhang, Y., Viney, N. R., Chiew, F. H. S., van Dijk, A. I. J. M., and Liu, Y. Y.: Improving hydrological and vegetation modelling using regional model calibration schemes together with remote sensing data, in: 19th International Congress on Modelling and Simulation, 12-16 December 2011, Perth, Australia, 3448-3454, 2011.

Zreda, M., Desilets, D., Ferré, T. P. A., and Scott, R. L.: Measuring soil moisture content non-invasively at intermediate spatial scale using cosmic-ray neutrons, Geophys. Res. Lett., 35, L21402, https://doi.org/10.1029/2008GL035655, 2008.

Zreda, M., Shuttleworth, W. J., Zeng, X., Zweck, C., Desilets, D., Franz, T., and Rosolem, R.: COSMOS: the COsmic-ray Soil Moisture Observing System, Hydrol. Earth Syst. Sci., 16, 40794099, https://doi.org/10.5194/hess-16-4079-2012, 2012. 